Article

\title{
Enhanced Tribological and Bacterial Resistance of Carbon Nanotube with Ceria- and Silver-Incorporated Hydroxyapatite Biocoating
}

\author{
Aditi Pandey ${ }^{1}$, Anup Kumar Patel ${ }^{1}$, Ariharan S. ${ }^{1}$, Vikram Kumar ${ }^{2}$, Rajeev Kumar Sharma ${ }^{1}$, \\ Satish Kanhed ${ }^{1}$, Vinod Kumar Nigam ${ }^{3}$, Anup Keshri ${ }^{4}$, Arvind Agarwal ${ }^{5}$ and \\ Kantesh Balani 1,* (iD \\ 1 Biomaterials Processing and Characterization Laboratory, Department of Materials Science and Engineering, \\ Indian Institute of Technology Kanpur, Kanpur-208016, Uttar Pradesh, India; aditip@iitk.ac.in (A.P.); \\ anupp7454@gmail.com (A.K.P.); ariharan@iitk.ac.in (A.S.); rksk@iitk.ac.in (R.K.S.); ksatish@iitk.ac.in (S.K.) \\ 2 Department of Mechanical Engineering, Indian Institute of Technology Kanpur, Kanpur-208016, \\ Uttar Pradesh, India; vikramk@iitk.ac.in \\ 3 Department of Bio-Engineering, Birla Institute of Technology, Mesra, Ranchi-835 215, Jharkhand, India; \\ vknigam@bitmesra.ac.in \\ 4 Department of Materials Science and Engineering, Indian Institute of Technology Patna, \\ Patna-801103, Bihar, India; anup@iitp.ac.in \\ 5 Department of Mechanical Engineering, Florida International University, Miami, FL 33172, USA; \\ agarwala@fiu.edu \\ * Correspondence: kbalani@iitk.ac.in; Tel.: +91-512-259-6194
}

Received: 30 March 2018; Accepted: 21 May 2018; Published: 24 May 2018

\begin{abstract}
Pertaining to real-life applications (by scaling up) of hydroxyapatite (HA)-based materials, herein is a study illustrating the role of carbon nanotube $(\mathrm{CNT})$ reinforcement with ceria $\left(\mathrm{CeO}_{2}\right)$ and silver (Ag) in HA on titanium alloy (TiAl6V4) substrate, utilizing the plasma-spraying processing technique, is presented. When compared with pure HA coating enhanced hardness (from 2.5 to $5.8 \mathrm{GPa}$ ), elastic modulus (from 110 to $171 \mathrm{GPa}$ ), and fracture toughness (from 0.7 to $2.2 \mathrm{MPa} \cdot \mathrm{m}^{1 / 2}$ ) elicited a reduced wear rate from $55.3 \times 10^{-5} \mathrm{~mm}^{3} \cdot \mathrm{N}^{-1} \cdot \mathrm{m}^{-1}$ to $2.1 \times 10^{-5} \mathrm{~mm}^{3} \cdot \mathrm{N}^{-1} \cdot \mathrm{m}^{-1}$ in HA-CNT-CeO $-\mathrm{Ag}$. Besides, an order of magnitude lower Archard's wear constant and a $41 \%$ decreased shear stress by for HA-CNT- $\mathrm{CeO}_{2}-\mathrm{Ag}$ coating depicted the effect of higher hardness and modulus of a material to control its wear phenomenon. Antibacterial property of $46 \%$ (bactericidal) is ascribed to $\mathrm{Ag}$ in addition to $\mathrm{CNT}-\mathrm{CeO}_{2}$ in HA. Nonetheless, the composite coating also portrayed exaggerated L929 fibroblast cell growth (4.8 times more than HA), which was visualized as flat and elongated cells with multiple filopodial protrusions. Hence, synthesis of a material with enhanced mechanical integrity resulting in tribological resistance and cytocompatible efficacy was achieved, thereupon making $\mathrm{HA}-\mathrm{CNT}-\mathrm{CeO}_{2}-\mathrm{Ag}$ a scalable potent material for real-life load-bearing implantable bio-coating.
\end{abstract}

Keywords: hydroxyapatite; ceria; silver; plasma-spraying; antibacterial; cytocompatible; filopodialprotrusions

\section{Introduction}

Hydroxyapatite (HA) has found its applications in biomedical applications (dentistry and orthopedics) due to its imperative property of biocompatibility and osteoconductivity (and is therefore bioactive) [1-3]. Biocompatibility and bioactivity is highest in hydroxyapatite. It is known that hydroxyapatite chemically bonds (directly) with hard tissues [4]. Clinically, HA coatings on bioinert 
metallic implants [5] have been applied. Despite the good biocompatibility of HA, its poor fracture toughness $\left(<1 \mathrm{MPa} \cdot \mathrm{m}^{1 / 2}\right)$ has restricted its use in orthopedic-load-bearing applications [6]. Therefore, HA coating on metals (higher mechanical strength, so stronger substrate) may provide increased strength and fatigue resistance. A thin coating of hydroxyapatite on the implant surface has been reported to improve on aspects encompassing bone implant contact, fixation of the implant, load-bearing capacity, and the osseointegration process, bone regeneration, and healing [7-9]. In this regard, HA is found to achieve a comparable biocompatibility and bioactivity for dental and skeletal implants comprised of titanium and its alloys $[5,10]$. Titanium and its alloys are commonly used as substrate for implants (orthopedic or dental) because of their lightness, excellent corrosion resistance, and mechanical properties [5], which make them better than other metals. They are biocompatible, but the ions released in the blood stream may have detrimental effects on the patient, leading to inflammation or allergies and toxic reactions [11-13]. By coating the titanium surface with a material mimicking the organic and inorganic phase of bone, a physiological transition may be created between its (titanium) non physiological surface and the bone tissue in the vicinity $[7,8]$.

Plasma spraying is a commercially existing technique used for the economic coating of HA for applications in real life [10]. Although new processing and coating techniques are available, their application is limited due to generation of non-biocompatible phases [14], non-homogeneity, degradation, amorphous and higher carbonated HA coating [15], weight loss and residue [16], and functionally restricted scalability [17]. However, micro-cracks and high porosity in plasma-sprayed HA coatings (also having peculiar brittleness of HA, low fracture toughness, making it mechanically inadequate) subject the coatings for delamination from the substrate. For mechanical property enhancement, reinforcement of the HA matrix with a second material is essential, for which the use of several materials like carbon nanotube (CNT), yttria stabilized zirconia (YSZ), alumina $\left(\mathrm{Al}_{2} \mathrm{O}_{3}\right)$, and silver (Ag) has been reported [18-20].

An attractive rare-earth compound, ceria $\left(\mathrm{CeO}_{2}\right)$, known for its antioxidant role [21], and $\mathrm{Ag}$ nanoparticles (NPs), a bactericidal agent, known to combat post-implant infections [22], have been used in an earlier work [23] synergistically into the HA matrix to achieve antioxidant, antibacterial, and cytocompatible spark plasma sintered composites for orthopedic applications. There was an enhancement in hardness by 1.6 times (from $5 \mathrm{GPa}$ to $9 \mathrm{GPa}$ ), elastic modulus by 1.4 times (from $121 \mathrm{GPa}$ to $168 \mathrm{GPa}$ ), and fracture toughness by 4.2 times fracture toughness (from $0.2 \mathrm{MPa} \cdot \mathrm{m}^{1 / 2}$ to $\left.0.9 \mathrm{MPa} \cdot \mathrm{m}^{1 / 2}\right)$ by $\mathrm{Ag}$ and $\mathrm{CeO}_{2}$ reinforcement in $\mathrm{HA}$. While the mechanical property improved $(H, E$, and $\left.K_{I C}\right)$, it was observed that it reached only to $0.9 \mathrm{MPa} \cdot \mathrm{m}^{1 / 2}$, which is again lesser than that needed (toughness of bone, $2.3 \mathrm{MPa} \cdot \mathrm{m}^{1 / 2}$ ) [24]. Therefore, addition of CNT into the HA matrix can be a possible route attributed to their exceptional mechanical properties (Young's modulus) and physical properties as well as good biocompatibility $[25,26]$. The CNT is also found to possess a hydrophobic nature (may be essential for protein and cell adsorption [23]) and are lightweight [27]. CNT-based composite materials exhibit biocompatibility without cytotoxicity as an important property for biomedical orthopedic and cardiovascular applications [28] due to its reported bioactivity [29-31]. Plasma-sprayed HA-4 wt \% CNT coatings depicted unrestricted human osteoblast hFOB cell growth and also showed apatite precipitation and mineralization on the CNT surface [25], which acts as crystallization site for apatite crystal growth. Balani et al. also demonstrated that HA-4 wt \% CNT plasma sprayed coating was found to have uniformly distributed undamaged CNTs and fracture toughness enhanced by $56 \%$ [25]. HA-4 wt \% CNT composites and $\mathrm{HA}-\mathrm{Al}_{2} \mathrm{O}_{3}-\mathrm{CNT}$ coatings have also shown a wear resistance enhancement of $66 \%$ [32] and 68 times [33], respectively, when compared to that of HA due enhanced hardness, modulus, and fracture toughness. Hence, CNTs incorporation may improve the mechanical properties of HA coatings without affecting their biocompatible properties [34-36].

Therefore, the novelty of the present work lies in fabricating a composite coating comprising CNT reinforcement along with $\mathrm{CeO}_{2}$ and $\mathrm{Ag}$ NPs in HA on a titanium alloy (TiAl6V4) substrate to achieve (i) higher mechanical properties (hardness and toughness) (ii) without compromising the antibacterial 
and cytocompatible efficacies in comparison to HA, thereby extending from laboratory scale to real-life improvements in the life of body inserts and implants for human healthcare.

\section{Materials and Methods}

\subsection{Processing}

Irregular HA (abbreviated as HA, 10-50 $\mu \mathrm{m}$ ), blended with 4 wt \% CNT (HA-4C, 40-70 nm diameter, 95\%+ purity, $2 \mu \mathrm{m}$ length, Nanostructured and Amorphous Materials Inc., Houston, TX, USA), 4 wt \% CNT-5 wt \% $\mathrm{CeO}_{2}$ (HA-4C-5Ce, $\mathrm{CeO}_{2}$ NPs were of 60-100 nm, from Inframat Advanced Materials, Manchester, CT, USA), and 4 wt \% CNT-5 wt \% CeO $2-5$ wt \% Ag (HA-4C-5Ce-5Ag, Ag NPs were of 80-100 nm, procured from Inframat Advanced Materials, Manchester, CT, USA) in a jar mill for $3 \mathrm{~h}$. Plasma sprayed coatings were deposited on TiAl6V4 substrate using Praxair SG 100 gun.

Following were the parameters used during plasma spraying: power $(24 \mathrm{~kW})$, primary gas $\mathrm{Ar}$ (30 slm), secondary gas He (28 slm), carrier gas Ar (25.5 slm), standoff distance (100 mm), and feed rate ( 3 grams per minute). The coating thickness was targeted to be around $\sim 100-120 \mu \mathrm{m}$ for all the coatings.

\subsection{Phase, Microstructural Characterization and Mechanical Characterization}

The samples were cloth polished by final alumina suspension (particle size, $0.22 \mu \mathrm{m}$ ). X-ray diffraction (XRD, Rich-Seifert, Mannheim, Germany), 2000D diffractometer, at $25 \mathrm{kV}$ and $15 \mathrm{~mA}$, having $\mathrm{Cu}-\mathrm{K} \alpha(\lambda=1.541 \AA)$ radiation at a scan rate of $0.5^{\circ} / \mathrm{min}$, and a step size of $0.02^{\circ}$, was used for the phase analysis studies. The cross-section of the samples was examined for the morphological characterization, and the coating thickness was thereby determined via Scanning Electron Microscopy (SEM; SUPRA40VP, Carl Zeiss NTS GmbH, Oberkochen, Germany). Raman spectroscopy (WITec $\mathrm{GmbH}$, Ulm, Germany, Alpha 300) was utilized for plasma-sprayed coatings to investigate the presence of CNTs.

The polished samples were subjected to Vickers microhardness tester with a load of $200 \mathrm{~g}$ and a dwell time of $10 \mathrm{~s}$ for estimating hardness of the plasma sprayed HA coatings. In-order to calculate the fracture toughness, a load of $500 \mathrm{~g}$ was used for $10 \mathrm{~s}$ dwell time. For radial crack length measurement, SEM images of the indents with the cracks were taken.

\subsection{Tribological Analysis of HA-Based Coatings}

The friction and wear testing was performed by the ball on disc method by Nanovea Tribometer. For a typical experiment, a $6 \mathrm{~mm}$ diameter stainless steel ball was rotated on the samples (in a circular wear track). Rectangular shaped samples of $5 \mathrm{~mm} \times 5 \mathrm{~mm} \times 2 \mathrm{~mm}$ are clamped on sample stage. A load of $10 \mathrm{~N}$ was applied with sliding speed of $150 \mathrm{rpm}$ and for a duration of $90 \mathrm{~min}$. The worn surface profiles were obtained by 3D optical surface profilometer (Contour GT-K, Bruker, Tucson, AZ, USA) used for the estimation of wear volume by Equation (1) [37]. The extent of damage and worn surfaces of HA-based coatings were further imaged by scanning electron microscope (W-SEM, JSM-6010LA, JEOL, Freising, Germany).

$$
\text { Wear volume }=\pi\left(d_{2}-d_{1}\right) h \times w
$$

where $d_{2}$ and $d_{1}$ are the outer and inner diameter of wear track, respectively, $h$ is the depth, and $w$ is the width of wear track.

\subsection{Wettability and Protein Adsorption}

The wettability (hydrophobicity/hydrophilicity) of the surface was measured by water contact angle on the surface of each sample $(n=3$, with repetition of ten times on each) by a contact angle 
goniometer (Data-physics Contact Angle System OCA). The protein (bovine serum albumin, BSA) adsorption behavior was quantified by a standard protocol according to the bicinchoninic acid assay kit (Cat. \# 786-570,786-571, G-biosciences). Samples $(n=3)$ in a 24-well plate were introduced with protein concentration (of $2 \mathrm{mg} / \mathrm{mL}$ ) and incubated at $37^{\circ} \mathrm{C}$ for $24 \mathrm{~h}$. The non-adhered proteins were washed (after incubation) by rinsing with 1XPBS. ELISA plate reader was used to evaluate the concentration of the adsorbed proteins at absorbance of $540 \mathrm{~nm}$.

\subsection{Antimicrobial Test}

The antibacterial activity of the HA-based coatings was studied by Gram-negative bacteria (E. coli; MCC2079). The samples were polished, autoclaved, rinsed with ethanol, and washed thoroughly with 1 XPBS before seeding. In a 24 -well culture plate, $200 \mu \mathrm{L}$ bacterial solutions ( 0.1 optical density) were seeded on each of the samples (triplicate samples tested for three different times). The samples were then incubated at $37^{\circ} \mathrm{C}$ for $4 \mathrm{~h}$, after which they were washed thoroughly with 1XPBS to remove the non-adhered bacterial cells. The samples were finally analyzed qualitatively (by scanning electron microscopy) and quantitatively (by MTT assay). The adhered bacterial cells were fixed first with $3 \%$ glutaraldehyde (for $20 \mathrm{~min}$ ), followed by $0.1 \mathrm{M}$ sodium cacodylate (for $15 \mathrm{~min}$ ), and then $0.1 \mathrm{M}$ sucrose (for $15 \mathrm{~min}$ ). After rinsing with 1XPBS again, samples were dehydrated using serially diluted alcohol series (for $10 \mathrm{~min}$ each) and dried finally by hexamethyldisilazane (HMDS, critical point dryer). Samples were eventually sputter-coated with gold for the SEM imaging (SEM; SUPRA40VP, Carl Zeiss NTS GmbH, Oberkochen, Germany).

In order to determine metabolic activity/viability of bacterial cells, MTT assay (MTT: (3(4,5dimethylthiazol-2-yl)-2,5-diphenyl tetrazolium bromide), Amresco, Life Science Research Product \& Biochemicals, Logan, UT, USA) was utilized. A 1:10 ratio of MTT: PBS was added onto each cultured sample and incubated at $37^{\circ} \mathrm{C}$ for $2 \mathrm{~h}$. MTT forms the formazan crystals upon reacting with viable cells, which are further dissolved by dimethyl sulphoxide (DSMO) producing a purple color. The absorbance of the purple colored solution was read at $570 \mathrm{~nm}$, by using an ELISA plate reader (ultraviolet-vis BioTek, Winooski, VT, USA) [38].

\subsection{Cytocompatibility Test}

The L929 mouse fibroblast (L929 NCCS Pune) were used for conducting in vitro tests. The cells were cultured in complete medium consisting of Dulbecco's modified eagles-base medium supplemented with fetal bovine serum (Cat no. F2442, Sigma Aldrich, Munich, Germany) and 1\% of antibiotic solution (penicillin, Cat no. A5955, Sigma Aldrich, Germany). Cultured cells were incubated at $37{ }^{\circ} \mathrm{C}, 5 \% \mathrm{CO}_{2}$, and $95 \%$ humidity, after which a sub-confluent cells (monolayer) was expanded by trypsin-EDTA solution (Cat no. T4049, Sigma Aldrich, Germany). For a typical experiment, pellets $(n=3)$ were seeded with a cell density of $2 \times 10^{4}$ cells $/ \mathrm{mL}$ in a 24 well plate and incubated for seven days. Scanning electron microscopy was utilized to image cell morphology on the sample surface. Quantification of cellular metabolic activity was performed by MTT assay at days 1, 3, and 7 . The protein adsorption and the MTT assay experiments were repeated three times.

\section{Results}

\subsection{Phase Analysis}

The phase characterization (XRD pattern) of hydroxyapatite, ceria, and silver powder, and their coatings on titanium alloy substrate are presented in Figure 1a. As can be seen from Figure 1, no additional peaks are obtained in XRD pattern except $\beta$-TCP at $2 \theta$ of $31.02^{\circ}$ corresponding to plane (0210), indicating that no major reaction has occurred in the constituent materials of coatings. The peaks corresponding to ceria can be observed from the planes (111), (311), and (220), with $2 \theta$ value of $28.61^{\circ}, 56.48^{\circ}$, and $47.59^{\circ}$ and the peaks for silver seen from planes (111), (200), (220) with $2 \theta$ value of $38.23^{\circ}, 44.34^{\circ}$, and $64.51^{\circ}$. 
Figure $1 \mathrm{~b}$ shows the Raman analysis of samples containing CNT. The D band at $1340 \mathrm{~cm}^{-1}$ and $\mathrm{G}$ band at $1572-1582 \mathrm{~cm}^{-1}$ in the spectra that corresponds to the characteristic of CNTs confirm its presence in the coatings, with ID/IG ratio ranging between $0.84-0.92$. The D band and G bands correspond to defects in the graphene sheets and stretching mode of graphitic backbone, respectively.

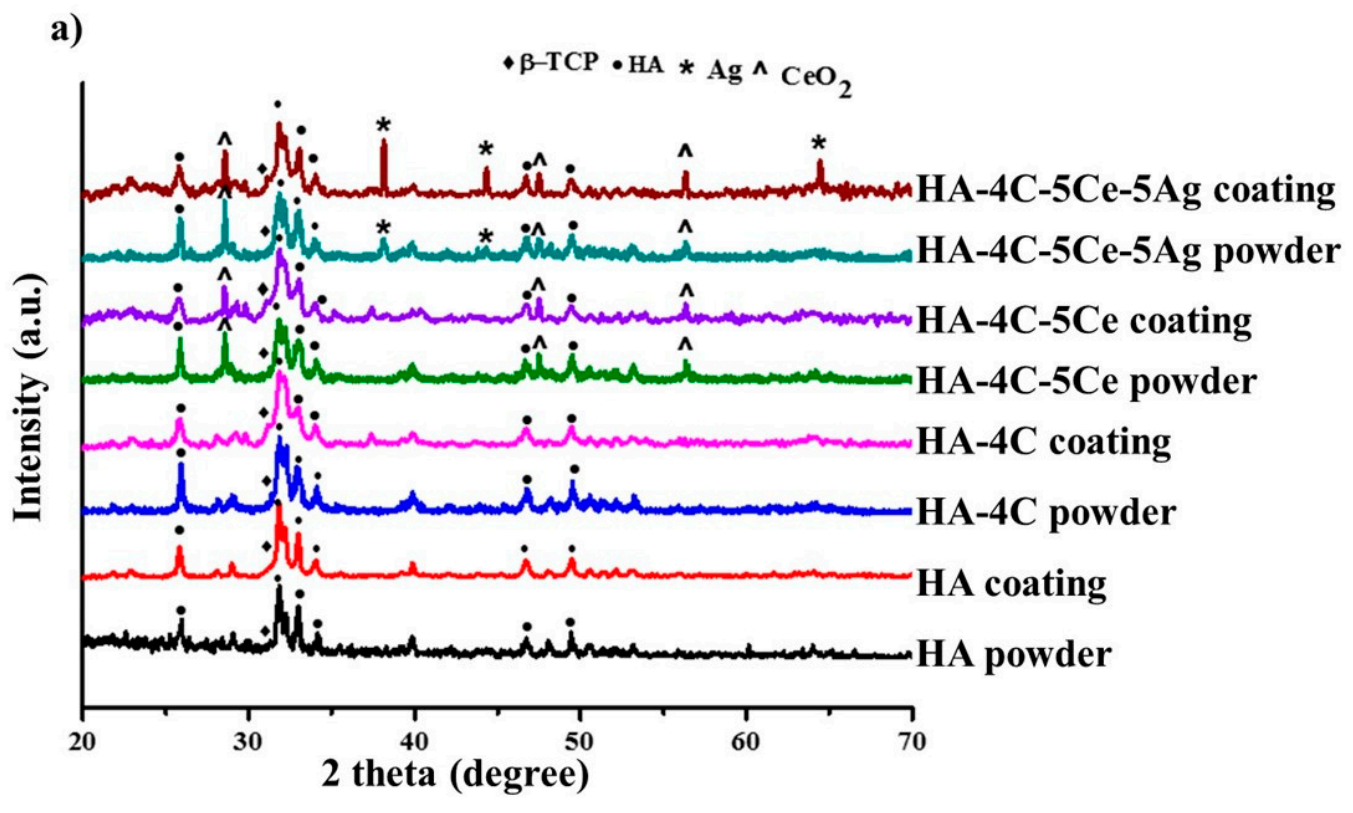

b)

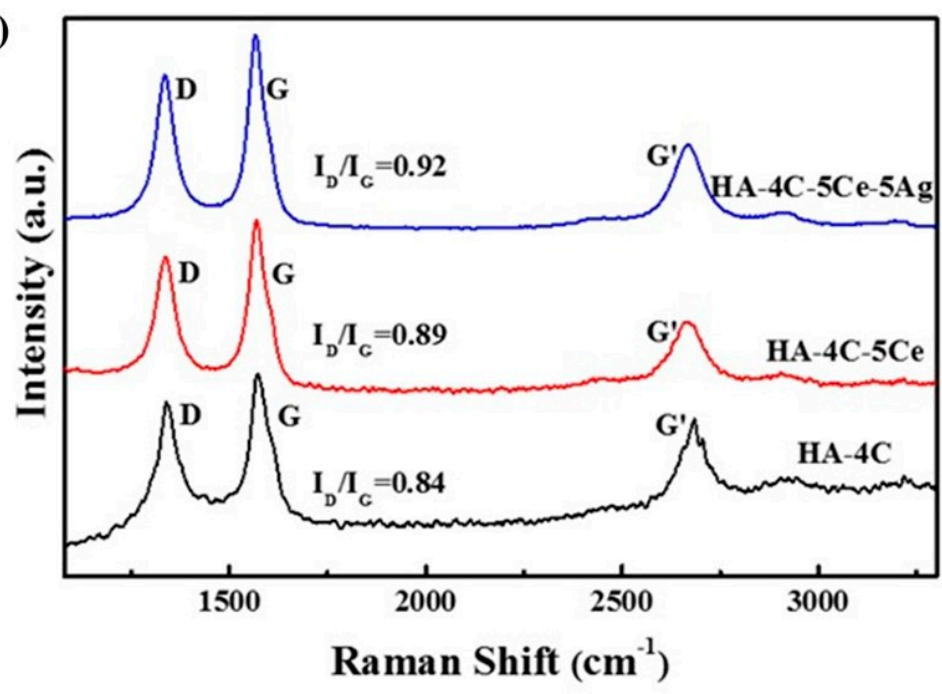

Figure 1. (a) X-ray diffraction (XRD) pattern of powders and coatings of hydroxyapatite (HA), HA-4C, HA-4C-5Ce, and HA-4C-5Ce-5Ag on TiAl6V4 substrate and (b) Raman spectra of carbon nanotube (CNT) containing composite coatings.

\subsection{Microstructural Characterization and Mechanical Properties}

The SEM images of cross sections of plasma sprayed coatings of HA, HA-4C, HA-4C-5Ce, and HA-4C-5Ce-5Ag on TiAl6V4 substrate are shown in Figure $2 \mathrm{a}-\mathrm{d}$ which depicts a lamellar structure showing no delamination from the TiAl6V4 substrate. Coatings are continuous, uniform and adherent. Thickness of the HA coating is observed to be 100-130 $\mu \mathrm{m}$ (Figure 2) due to which have not been found to chip off or delaminate after sample processing. All the coatings possess a similar nature with transverse cracks, with $\mu \mathrm{m}$ size porosity distributions. 

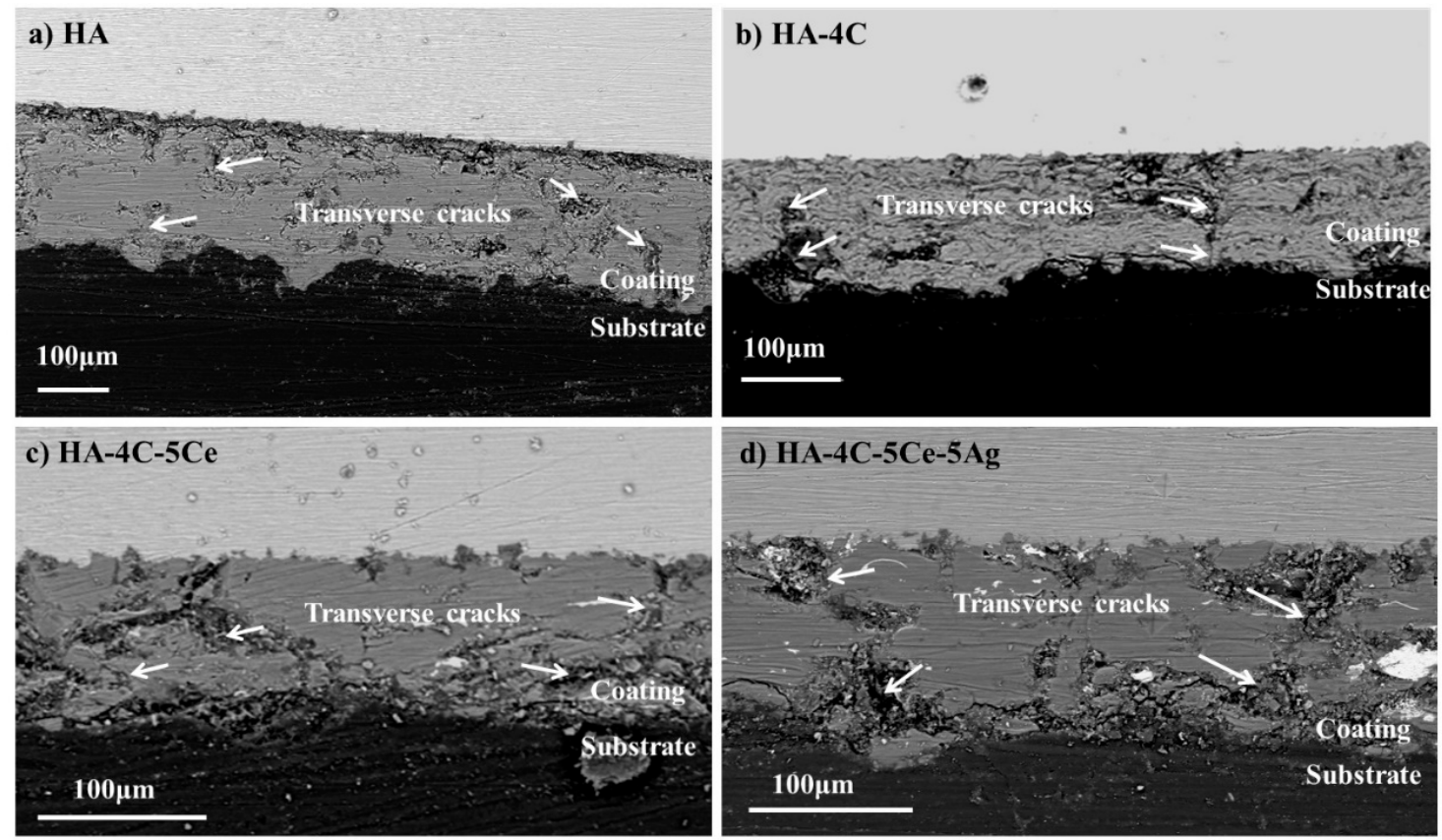

Figure 2. Cross sectional view of plasma sprayed coatings of (a) HA, (b) HA-4C, (c) HA-4C-5Ce, and (d) HA-4C-5Ce-5Ag.

The mechanical properties of the coatings are presented in Table 1. The hardness of HA was obtained to be $1.88 \mathrm{GPa}$, which increased to $3.95 \mathrm{GPa}$ with the addition of CNT (HA-4C) as also reported in the literature [25,32,33]. Increased hardness was recorded in HA-4C-5Ce-5Ag (5.8 GPa) in comparison to HA-4C-5Ce (4.13 GPa) due to Ag addition in the composite. Furthermore, the elastic modulus of the composite coatings was estimated by the rule of mixture, wherein, $110 \mathrm{GPa}$ for pure HA, 165.3 GPa for HA-4C, 170.9 GPa for HA-4C-5Ce, and 171.4 GPa for HA-4C-5Ce-5Ag, again following the similar trend reported in the literature [22,23].

Table 1. Abbreviations used and the mechanical properties $\left(H, E\right.$, and $\left.K_{I C}\right)$ of the coatings.

\begin{tabular}{ccccc}
\hline Plasma Sprayed Coatings & Abbreviations & $\boldsymbol{H}(\mathbf{G P a})$ & $\boldsymbol{E} / \boldsymbol{H}$ & $\boldsymbol{K}_{\boldsymbol{I C}}\left(\mathbf{M P a} \cdot \mathbf{m}^{\mathbf{1 / 2}}\right)$ \\
\hline Hydroxyapatite & $\mathrm{HA}$ & $1.88 \pm 0.88$ & 44 & 0.68 \\
Hydroxyapatite-CNT & $\mathrm{HA}-4 \mathrm{C}$ & $3.95 \pm 0.96$ & 41.8 & 0.89 \\
Hydroxyapatite-CNT-CeO & HA-4C-5Ce & $4.13 \pm 0.54$ & 41.4 & 1.12 \\
Hydroxyapatite-CNT-CeO 2 -Ag & HA-4C-5Ce-5Ag & $5.85 \pm 0.85$ & 29.3 & 2.12 \\
\hline
\end{tabular}

The fracture toughness was calculated by the Anstis' Equation (2) [39].

$$
K_{I C}=0.016(E / H)^{1 / 2} \times F / C^{3 / 2}
$$

where $H$ and $E$ are the hardness and elastic modulus of the coatings, $F$ is the load at which the cracks were generated, and $C$ is the critical crack length for all HA-based samples (shown in Figure 3a-d) from the indent center. The average fracture toughness of pure HA coating was found to be $0.68 \mathrm{MPa} \cdot \mathrm{m}^{1 / 2}$ and $0.89 \mathrm{MPa} \cdot \mathrm{m}^{1 / 2}$ for HA-4C, $1.12 \mathrm{MPa} \cdot \mathrm{m}^{1 / 2}$ for HA-4C-5Ce, and $2.12 \mathrm{MPa} \cdot \mathrm{m}^{1 / 2}$ for HA-4C-5Ce-5Ag. It can be observed that the fracture toughness increases by $\sim 1.3$ times with CNT addition, $\sim 1.6$ times with $\mathrm{CNT}$ and $\mathrm{CeO}_{2}$ addition, and $\sim 3.1$ times with synergistically reinforced $\mathrm{CNT}-\mathrm{CeO}_{2}-\mathrm{Ag}$. The toughening mechanisms in $\mathrm{CNT}$ is attributed to phenomena of CNT assisting in crack-bridging, crack-deflection, and CNT pull-outs [22], as observed from inset of Figure 3. 

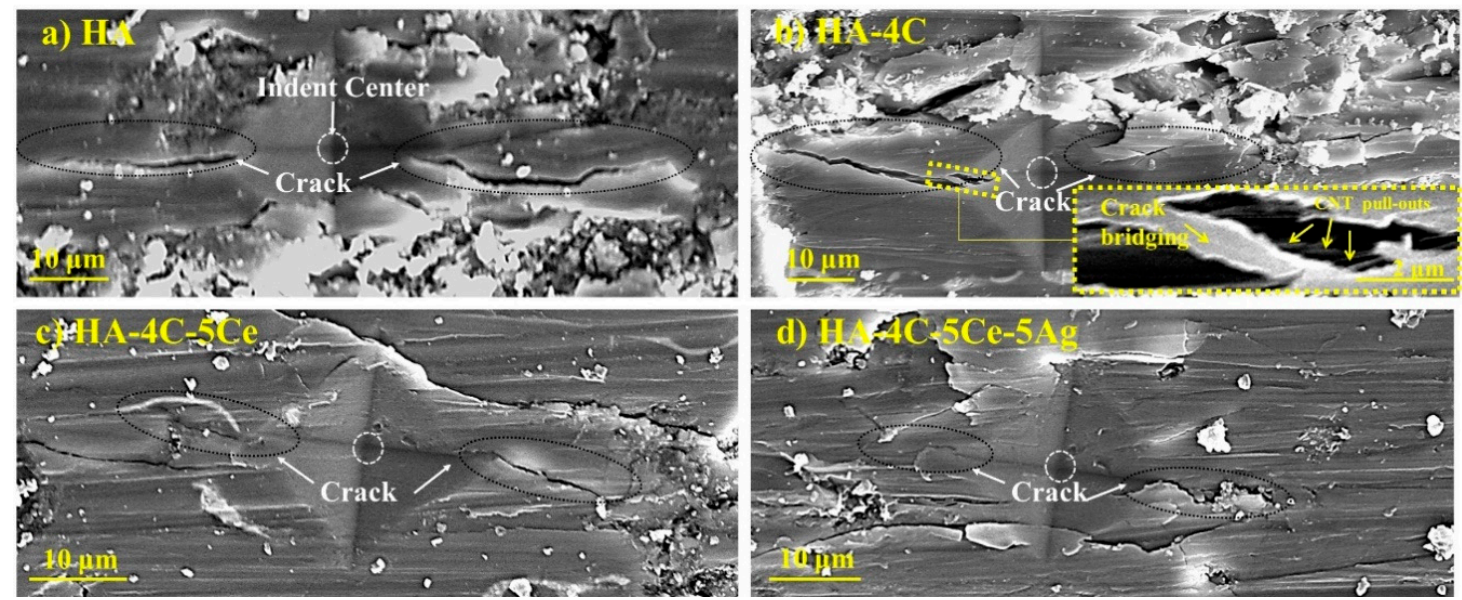

Figure 3. Propagating radial crack from the indent in plasma sprayed coatings of (a) HA, (b) HA-4C (inset depicting the crack showing CNT pull-outs and crack bridging phenomenon), (c) HA-4C-5Ce, and (d) HA-4C-5Ce-5Ag.

It can be noticed that the fracture toughness in $\mathrm{CNT}_{-} \mathrm{CeO}_{2}$-incorporated samples does not deteriorate (marginal enhancement, despite the brittle nature of $\mathrm{CeO}_{2}$ ceramic) in comparison to HA-CNT. In the case of HA-4C-5Ce-5Ag, the Ag NPs melt/liquefy due to its lower melting point of $960{ }^{\circ} \mathrm{C}$, and therefore it is realized that they contribute to the volumetric toughening by their homogenous distribution [22,40] in the HA matrix. This explains the increased toughness by Ag incorporation into the HA-4CNT coating. Furthermore, propagating crack tip (from stress) is shielded by the generated compressive stresses upon alloying yttria-doped tetragonal zirconia ceramics with $\mathrm{CeO}_{2}$ yielding higher toughness [41,42], and deformed Ag NPs (added into HA-4CNT matrix) absorb enhanced energy in a propagating crack (by crack tip blunting and bridging) [22]. The fractured surface of HA-4C-5Ce-5Ag (Figure 4) shows the presence of CNT, which is retained in the sample after processing. It can be inferred that isolated interfacial delamination of $\mathrm{CNT}$ or toughening provided by $\mathrm{CeO}_{2} \mathrm{NPs}$ contributing to enhanced toughness is feeble when compared to the highest toughness obtained for HA-4C-5Ce-5Ag layer, which is elicited by synergistic effect of the delaminated CNTs and the volumetric toughening rendered by the effect of Ag.

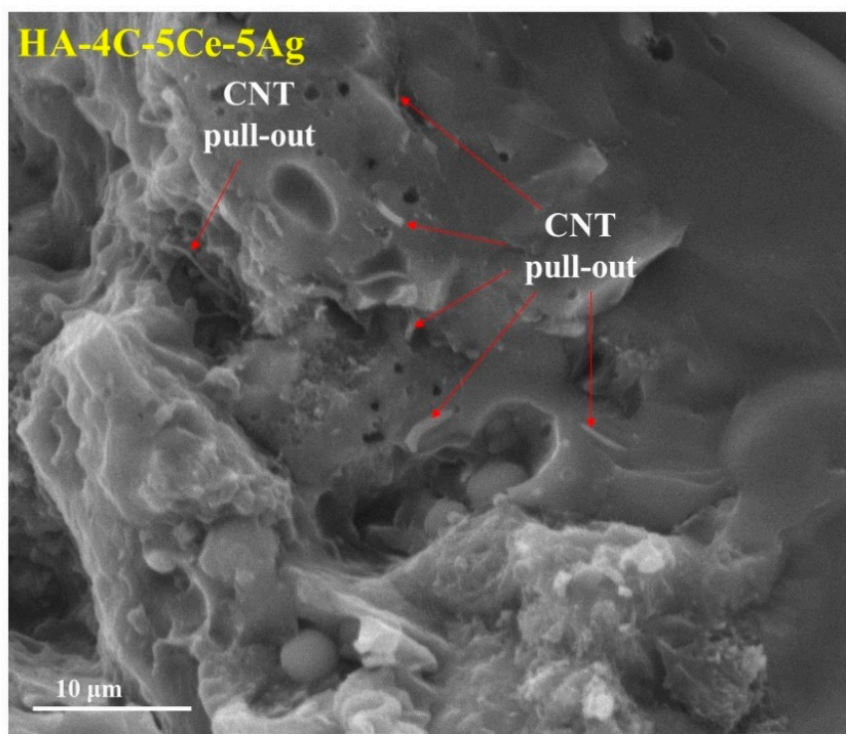

Figure 4. Fractured surface of HA-4C-5Ce-5Ag showing the CNT pull-outs. 


\subsection{Tribological Studies of HA-Based Coatings}

The coefficient of friction (COF) obtained during the tribology of HA-based coatings was found to decrease with $\mathrm{CNT} \mathrm{CeO} 2$ and/or Ag reinforcement (Figure 5). The $\mathrm{COF}$ during the steady state was found to be 1.5, 1.8, and 2 times lower than that of HA (COF: 0.16) for HA-4C (COF: 0.11), HA-4C-5Ce (COF: 0.09), and HA-4C-5Ce-5Ag (COF: 0.08), respectively. The reduced COF for CNT-incorporated samples can be attributed to the lubrication provided by a peeled-off graphene layer from CNT (by the applied shear force) and its deposition on the wear track [43]. Furthermore, $\mathrm{CeO}_{2}$ and $\mathrm{Ag} \mathrm{NPs}$ reinforcement into the HA matrix have also been reported to cause a 4.4 times reduction in COF (due to enhanced 1.6 times hardness and 4.2 times toughness) when compared to that of HA [44]. Factoring in the combined effects of appreciated mechanical properties $\left(E, H\right.$, and $\left.K_{I C}\right)$ by the reinforcing phases may be an important aspect decreasing the coefficient of friction.

Hertzian contact diameter (HCD) for counter body (stainless steel ball) and substrate (wear behavior of material) configuration is estimated by the following Equation (3) [45]:

$$
D=\left(\frac{3 R F_{n}}{4 E^{*}}\right)^{\frac{1}{3}}, \text { where } \frac{1}{E^{*}}=\frac{1-v_{1}^{2}}{E_{1}}+\frac{1-v_{2}^{2}}{E_{2}}
$$

where $F_{n}$ is the load, $R$ is the radius of the counter-body (ball), and $v_{1}$ and $v_{2}$ are the Poisson's ratio and $E_{1}$ and $E_{2}$ correspond to the Young's modulus of the steel ball and the substrate, respectively.

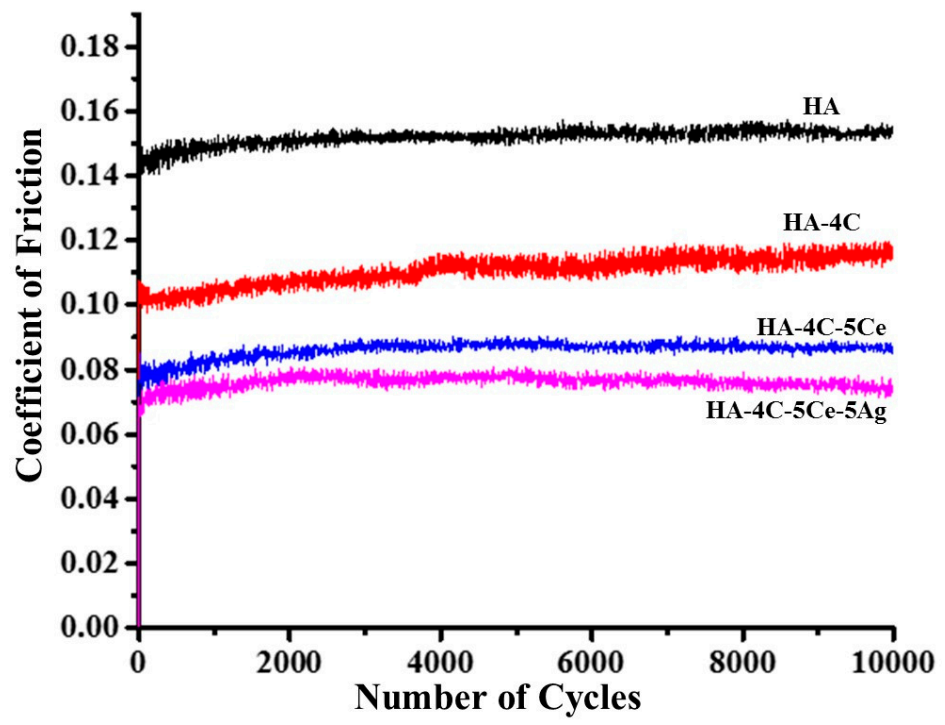

Figure 5. Plot representing coefficient of friction (COF) as a function of number of cycles during ball-on-disc of HA, HA-4C, HA-4C-5Ce, and HA-4C-5Ce-5Ag composites.

The HCD values for HA was estimated to be $\sim 66 \mu \mathrm{m}$, which decreased to $\sim 61 \mu \mathrm{m}$ for all the other composites (HA-4C, HA-4C-5Ce, and HA-4C-5Ce-5Ag), owing to higher elastic modulus (Table 1) (as HCD is primarily a function of modulus of mating material). Therefore, it can be said that the higher HCD (more sliding surface area, and thus more counter body-sample interaction) resulted in more surface damage/wear [45]. The change in HCD was not found to be very significant but is not the only criteria in determining wear resistance. Further, to estimate the generated stress levels relating to the damage caused, the Hertzian contact pressure $(H C P)$ and the shear stress was calculated by the following Equation (4) [44,45]:

$$
H C P=\left(\frac{6 F_{n}\left(E^{*}\right)^{2}}{3.14^{3} \times R^{2}}\right)^{\frac{1}{3}}
$$


where $F_{n}$ is the applied load and $R$ is the counter body radius. The value of $E^{*}$ is reported in Table 2 (from $H C D$ calculations of fretting), and the shear stress $(\tau)$ can be computed from the following relation:

$$
\tau=H C P \times C O F
$$

The shear stress for HA coating was estimated to be $173.7 \mathrm{MPa}$, which reduced to $140.6 \mathrm{MPa}$ (19\% reduction) with CNT incorporation, and $115 \mathrm{MPa}$ (33\% reduction) and $102.9 \mathrm{MPa}$ ( $41 \%$ reduction) with $\mathrm{CNT}-\mathrm{CeO}_{2}$ and $\mathrm{CNT}-\mathrm{CeO}_{2}-\mathrm{Ag}$ reinforcement, respectively. The attained wear resistance is also higher (25.9 times) for the $\mathrm{CNT}, \mathrm{CeO}_{2}$, and Ag-incorporated coatings attributed to the contact stresses leading to effective densification of the graphitic layers from CNT, providing lubrication and thus a decreased wear rate (Table 2). The high values of the pressure created during the wear of HA (no lubrication provided due to absence of CNTs) has resulted highest damage and thus eliciting a maximum wear rate $\left(176.1 \times 10^{-5} \mathrm{~mm}^{3} \cdot \mathrm{N}^{-1} \cdot \mathrm{m}^{-1}\right)$ amongst the coatings.

The scanning electron micrographs of the worn surfaces after the wear test of HA-based composite coatings are represented in Figure $6 a-d$. Severe damage (a worn surface) can be seen by the extensive delamination, cracks, and pits in the HA coatings (Figure 6a). However, it was realized that with $\mathrm{CNT}, \mathrm{CeO}_{2}$ and/or Ag reinforcement, restricted damage occurred due to recognized smoothening (Figure $6 \mathrm{~b}-\mathrm{d}$, roughness after wear in Table 2), which may be due to the lubrication from the graphene layers of $\mathrm{CNT}$ and the abrasion resistance imparted by the coatings [46]. The synergistically reinforced HA-4C-5Ce-5Ag (Figure 6d), exhibited least damage (highest surface smoothening effects). The high shear stress-initiated (140.6 MPa) CNT pull-outs in HA-4C (also due to lower $\mathrm{H}$ and $\mathrm{K}_{I C}$ than HA-4C-5Ce and HA-4C-5Ce-5Ag) agglomerated and discontinuous graphene tribofilm, as also reported earlier [43]. This tends to cause a disparity of surface smoothening in comparison to HA-4C-5Ce (roughness, $6 \mu \mathrm{m}$ ) and HA-4C-5Ce-5Ag (lesser CNT pull-outs, resulting in lowered graphene layers agglomeration and thereby the smoothening is higher, with a roughness of $5 \mu \mathrm{m}$ ) [43,46]. Therefore, the wear resistance attained in case of HA-4C is lower (discontinuous tribofilm) than HA-4C-5Ce and HA-4C-5Ce-5Ag (smoother tribofilm, roughness of $5 \mu \mathrm{m}$ ). However, the wear resistance in $\mathrm{HA}-4 \mathrm{C}$ is higher than HA due to the tribofilm deposition (though uneven, rough, $10 \mu \mathrm{m}$ ), which (tribofilm) is not there in pure HA coating. Thus, it is the combined effect of shear stress (leading to matrix smoothening of CNTs by its graphene layers) and mechanical integrity ( $H$ and $K_{I C}$, Table 1) that results in the maximum wear resistance in HA-4C-5Ce-5Ag coating. The 25.9 times higher wear resistance (Table 2) is further supported by the decreased lateral force generated at same normal force, which is attributed to the reduced COF and reduction of damage (worn surface area) in the wear track [32].

The wear track profiles and the occurred damage (i.e., wear volume) were determined by optical profilometry (Figure 7a-d). Table 2 presents the reduction in the worn volume with $\mathrm{CNT}, \mathrm{CeO}_{2}$, and/or $\mathrm{Ag}$ incorporation in HA. The wear volume of $0.062 \pm 0.007 \mathrm{~mm}^{3}$ was obtained in HA (Figure 7a), which decreased to $0.023 \pm 0.005 \mathrm{~mm}^{3}$ in HA-4C (by 3 times, Figure $7 \mathrm{~b}$ ). Further a remarkable reduction of 20 times was found to be in HA-4C-5Ce sample (wear volume, $0.003 \pm 0.001 \mathrm{~mm}^{3}$, Figure 7c) with the least volume of $0.002 \pm 0.001 \mathrm{~mm}^{3}$ obtained in HA-4C-5Ce-5Ag coating, Figure $7 \mathrm{~d}$, which is 30 times lesser than that of HA.

Table 2. Characterization from ball on disc test of HA-based plasma-sprayed samples.

\begin{tabular}{|c|c|c|c|c|c|c|c|}
\hline Sample & COF & $\begin{array}{c}W_{\mathrm{R}} \\
\left(\times 10^{-6} \mathrm{~mm}^{3} \cdot \mathrm{N}^{-1} \cdot \mathrm{m}^{-1}\right)\end{array}$ & $\begin{array}{c}\text { Roughness } \\
\text { after Wear }(\mu \mathrm{m})\end{array}$ & $\begin{array}{c}E^{*} \\
(\mathrm{GPa})\end{array}$ & $\begin{array}{r}\mathrm{HCD} \\
(\mu \mathrm{m})\end{array}$ & $\begin{array}{c}\tau \\
(\mathrm{MPa})\end{array}$ & $\begin{array}{c}\text { Wear } \\
\text { Resistance }\end{array}$ \\
\hline $\mathrm{HA}$ & $0.16 \pm 0.01$ & $176.1 \pm 7.0$ & 12 & 77.1 & 66.3 & 173.7 & Base \\
\hline HA-4C & $0.11 \pm 0.01$ & $54.7 \pm 5.2$ & 10 & 98.5 & 61.1 & 140.6 & 3.2 times \\
\hline $\mathrm{HA}-4 \mathrm{C}-5 \mathrm{Ce}$ & $0.09 \pm 0.01$ & $9.7 \pm 0.8$ & 6 & 100.3 & 61.7 & 115 & 18.1 times \\
\hline HA-4C-5Ce-5Ag & $0.08 \pm 0.01$ & $6.8 \pm 0.2$ & 5 & 99.5 & 61.9 & 102.9 & 25.9 times \\
\hline
\end{tabular}



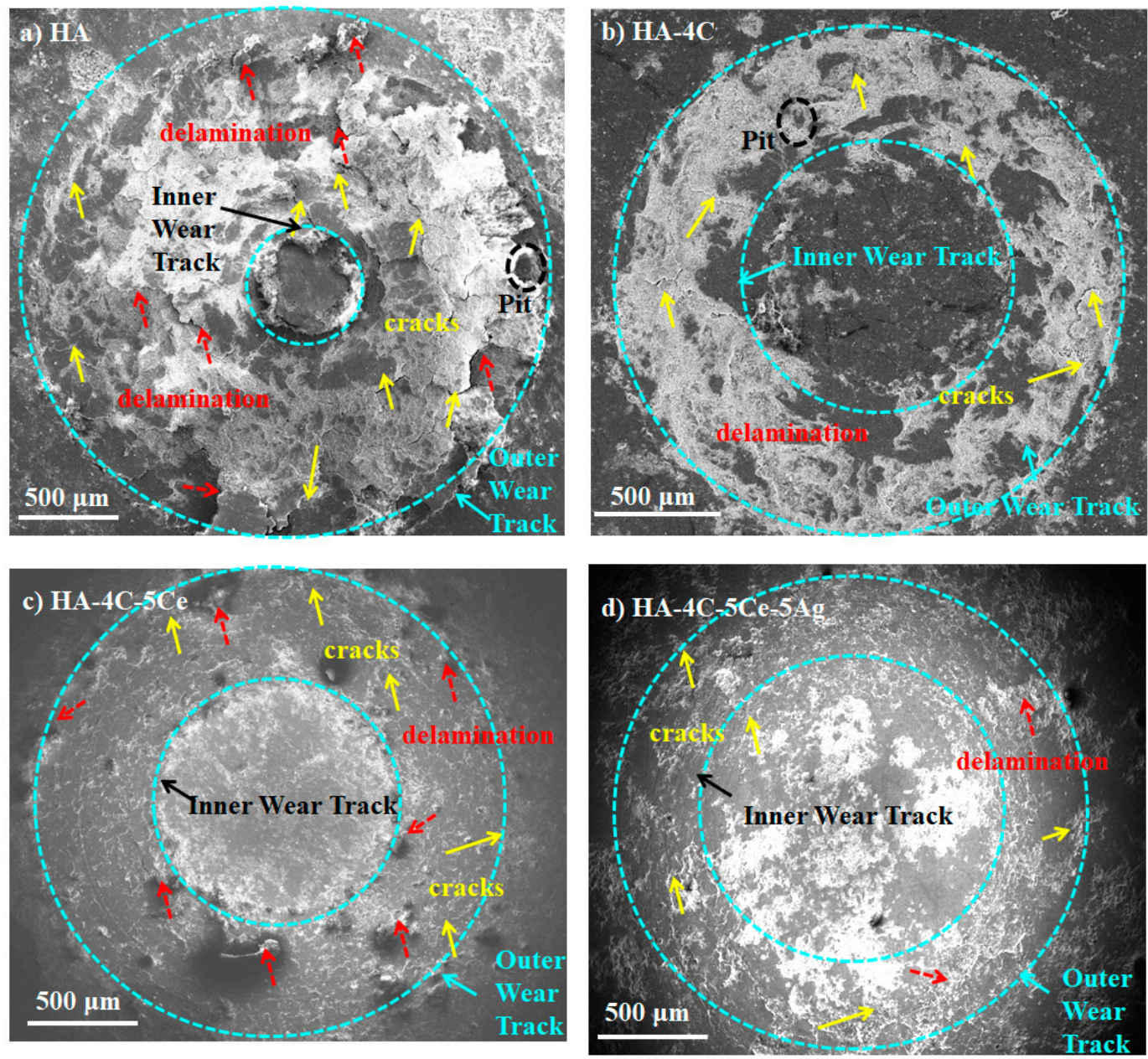

Figure 6. Micrographs showing the worn surface scar of (a) HA, (b) HA-4C, (c) HA-4C-5Ce, and (d) HA-4C-5Ce-5Ag (yellow and red arrows show cracks and delamination, respectively).

Wear rate $\left(W_{R}\right)$ was calculated using the following Equation (5) and shown in Table 2.

$$
W_{R}=\frac{W_{v}}{\operatorname{Load} \times S}
$$

where $S$ is the sliding distance. The wear rate was estimated to be highest for HA, $176.1 \times 10^{-6}$ $\mathrm{mm}^{3} \cdot \mathrm{N}^{-1} \cdot \mathrm{m}^{-1}$, which was reduced by 3 times to $54.7 \times 10^{-6} \mathrm{~mm}^{3} \cdot \mathrm{N}^{-1} \cdot \mathrm{m}^{-1}$ for $\mathrm{HA}-4 \mathrm{C}$, with a further reduction of 18 times to $9.7 \times 10^{-6} \mathrm{~mm}^{3} \cdot \mathrm{N}^{-1} \cdot \mathrm{m}^{-1}$ for HA-4C-5Ce. A reduction of 26 times in the wear rate for HA-4C-5Ce-5Ag coating is attributed to an increased hardness and toughness, as shown in Table 1 . The achieved wear rate in the coatings can also be correlated with the tribofilm formation (and thickness) with $\mathrm{CNT}, \mathrm{CeO}_{2}$, and $\mathrm{Ag}$ reinforcement as seen by the SEM images in Figure $5 \mathrm{~b}-\mathrm{d}$.

The relation of the bulk hardness $(H)$ of the material with the wear volume can be studied using the Archard equation (to evaluate the wear constant, $k$ ) via Equation (6).

$$
k=\frac{W_{v} \times H}{P \times L}
$$

where $H$ is the hardness of coatings, $P$ is load applied, and $L$ is sliding distance. Upon application of load, the resistance in wear loss by the hardness of the material portrays the wear constant. The wear constant of $13.8 \times 10^{-3}$ was estimated for pure HA coating, illustrating highest wear loss. For HA-4C, the wear constant was found to be decreased to $6.7 \times 10^{-3}$. The extremely low values of wear constant, 
of $1.3 \times 10^{-3}$ and $1.2 \times 10^{-5}$, was computed for HA-4C-5Ce and HA-4C-5Ce-5Ag, respectively, owing to enhanced hardness (due to effect of synergistic addition of $\mathrm{CNT}, \mathrm{CeO}_{2}$ and $\mathrm{Ag}$ ), which thereupon resulted in the least wear rate (wear resistance increased by 18 and 26 times by HA-4C-5Ce and HA-4C-5Ce-5Ag, respectively).

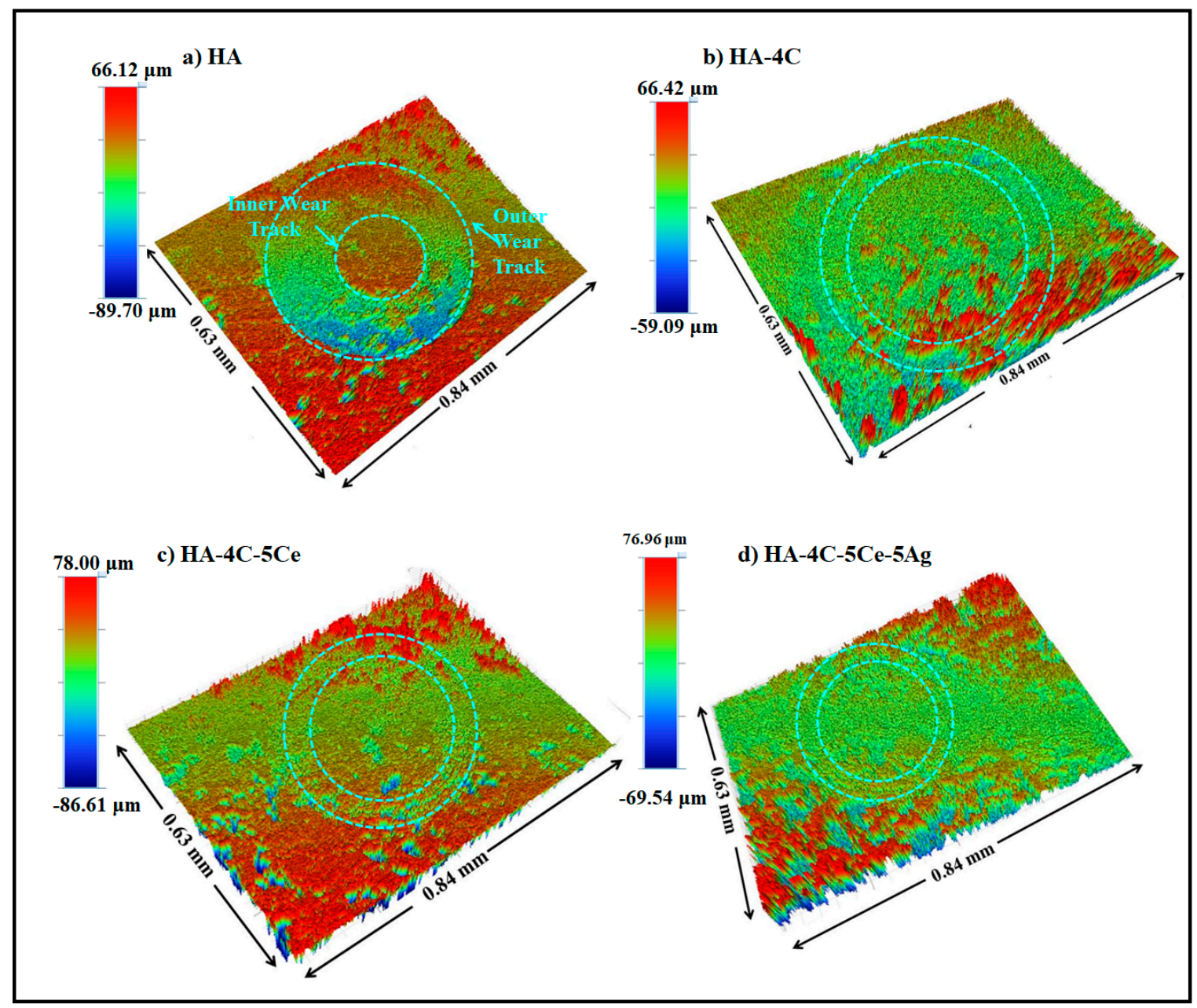

Figure 7. Three-dimensional images (a-d) observed by surface profilometery of the worn surface scar of HA, HA-4C, HA-4C-5Ce, and HA-4C-5Ce-5Ag.

In order to understand the effect of wear on the CNT reinforced plasma sprayed coatings, Raman spectroscopy was utilized. The $\mathrm{I}_{\mathrm{D}} / \mathrm{I}_{\mathrm{G}}$ ratio in the coatings after wear (Figure 8) was increased from 0.95 to 1.02 in comparison to that before wear ranging from 0.84 to 0.92 (Figure $1 \mathrm{~b}$ ), which may be attributed to an increased defect in the carbon structure by the shear stress generated during the wear phenomenon (causing CNT distortion and peeling of its graphene layers). It can be observed from the Raman spectra that a maximum of $1.01 \mathrm{I}_{\mathrm{D}} / \mathrm{I}_{\mathrm{G}}$ is obtained in the HA-4CNT coating, which may be attributed to highest $140.6 \mathrm{MPa}$ shear stress upon wear due to lowest $H$ and $K_{I C}$ among all CNT reinforced coatings). However, a significant wear resistance (3 times) is obtained in comparison to pure HA due to the peeled off graphene layers (leading to its agglomeration). 


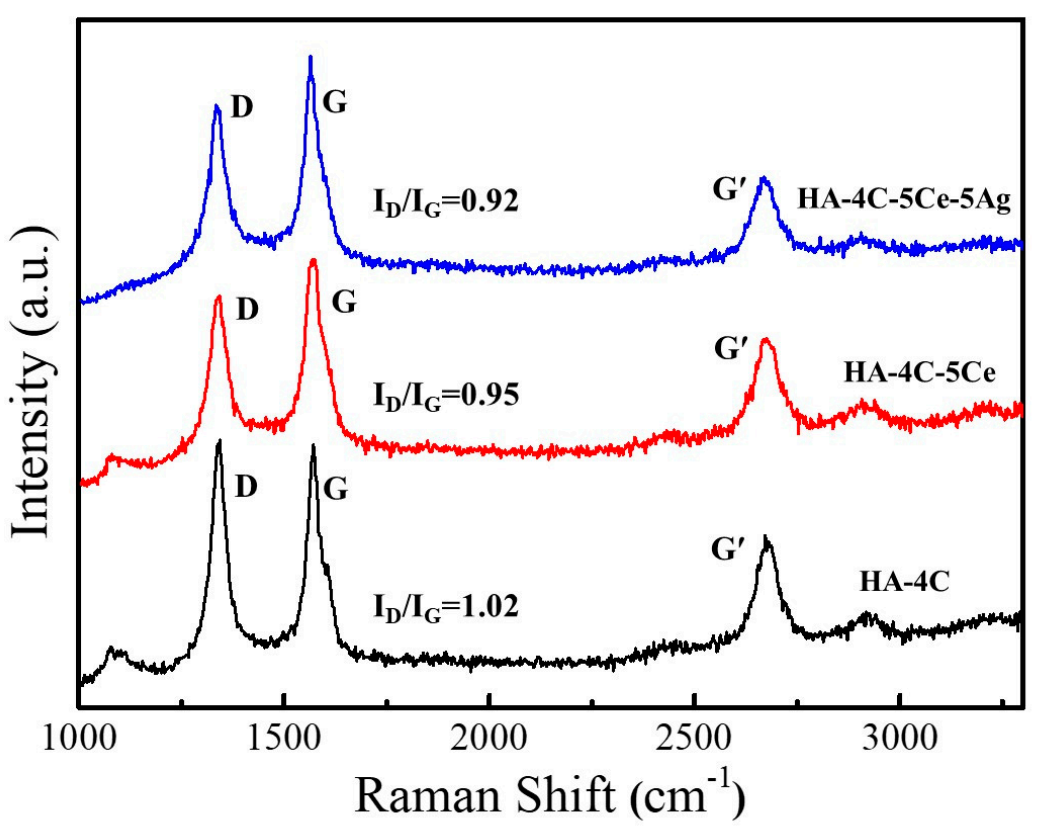

Figure 8. Raman spectra after wear of HA-4C, HA-4C-5Ce, and HA-4C-5Ce-5Ag plasma-sprayed coatings.

\subsection{Wettability Studies and Its Role in Protein Adsorption of HA-Based Coatings}

The water contact angles (WCA) on HA-based coatings is shown in Table 3. A contact angle of $74^{\circ}$ was obtained on HA (hydrophilic surface), which increased to $104^{\circ}$ on $\mathrm{HA}-4 \mathrm{C}$ and $112^{\circ}$ on $\mathrm{HA}-4 \mathrm{C}-\mathrm{Ce}$ coating, showing an increase in hydrophobicity by $\mathrm{CeO}_{2}$ and/or $\mathrm{CNT}$ reinforcement. This is due to the inherent hydrophobic nature of $\mathrm{CNT}$ [47] and $\mathrm{CeO}_{2}$ [48] (shielding effect of the $4 \mathrm{f}$ orbital by outer $5 \mathrm{~s}^{2} \mathrm{p}^{6}$ shell [48-50]). When considering HA-4C-Ce-Ag substrate, the contact angle was observed to be $97^{\circ}$ because of comparatively lesser hydrophobicity of silver $[23,51]$ in comparison to $\mathrm{CNT}_{\text {or }} \mathrm{CeO}_{2}$. However, the surface was found to be hydrophobic when compared to the hydrophilic HA.

It is known that surface properties like hydrophobicity and electronic charge affect protein adsorption and cell adhesion up to $48 \mathrm{~h}[52,53]$. From the protein adsorption presented in Table 3 , it can be observed that BSA adsorption of $2.1 \mu \mathrm{g} \cdot \mathrm{mm}^{-2}$ was obtained on pure HA coating. With an increase in hydrophobicity, the protein adsorption was found to increase to $3.4 \mu \mathrm{g} \cdot \mathrm{mm}^{-2}(1.6$ times) for HA-4C. A BSA adsorption of 2.0 times than HA $\left(4.2 \mu \mathrm{g} \cdot \mathrm{mm}^{-2}\right)$ was obtained on HA-4C-5Ce-5Ag (despite its lower contact angle than $\mathrm{HA}-4 \mathrm{C}$ ) due to the combined action of hydrophobicity (of $\mathrm{CNT}-\mathrm{CeO}-\mathrm{Ag}$ ) and chemistry of Ag (spontaneous adsorption of proteins on surface of a silver-coated implant [54,55], and specific binding of silver with -SH groups of BSA protein [56,57]). It can be noticed that HA-4C-5Ce elicited a maximum adsorption of $5.0 \mu \mathrm{g} \cdot \mathrm{mm}^{-2}$ (2.4 times higher than that on pure HA) is again attributed to the effect of its highest hydrophobicity. The role of hydrophobicity (solely acting as the main driving force due to very large difference in contact angle by almost $15^{\circ}$ in comparison to HA-4C-5Ce-5Ag) may be more than the combined effect of hydrophobicity and surface chemistry as in $\mathrm{HA}-4 \mathrm{C}-5 \mathrm{Ce}-5 \mathrm{Ag}$. 
Table 3. Water contact angles (WCA), the corresponding BSA adsorption, and cell density improvement on the HA-based coatings ( ${ }^{*}$ indicates $p$ values of mean adsorbed proteins on composites when compared to HA control: <0.0001).

\begin{tabular}{|c|c|c|c|}
\hline Sample & Contact Angle (Degree) & $\begin{array}{l}\text { Protein Adsorption } \\
(\mu \mathrm{g} / \mathrm{mm} 2)\end{array}$ & $\begin{array}{l}\text { Day } 1 \text { Cell Density } \\
\text { Improvement }\end{array}$ \\
\hline HA & & $2.1 \pm 0.1$ & 1 \\
\hline HA-4C & & $3.4 \pm 0.1 *$ & 2.7 times \\
\hline HA-4C-5Ce & & $5.0 \pm 0.1 *$ & 3.7 times \\
\hline HA-4C-5Ce-5Ag & & \pm 0.1 * & 3.0 times \\
\hline & $97.0^{\circ} \pm 2.0$ & & \\
\hline
\end{tabular}

\subsection{Antibacterial Efficacy of Silver-Reinforced HA Coating}

The adhesion of E. coli bacteria on HA-based coatings are shown in Figure 9a-d after $4 \mathrm{~h}$ incubation time. The scanning electron micrographs shows that when compared to HA (Figure 9a), the bacterial adhesion increases by CNT addition (Figure 9b), which has also been reported by Herkendell et al. [22]. A similar bacterial adhesion on HA-4C-Ce reveals the inert nature of $\mathrm{CeO}_{2}$ toward E. coli (Figure 9c). The least bacterial adhesion was observed on HA-4C-5Ce-Ag sample, Figure 9d, due to the silver reinforcement, attributed to its bactericidal role. The -SH group of many enzymes are targeted by Ag ions, thereupon restricting protein synthesis. Furthermore, the bacterial DNA is also denatured by Ag, thereby killing the bacteria [19].

The quantitative estimation of live bacteria, by MTT assay (Figure 9e), also correlated well with the bacterial density in the SEM images (Figure 9a-d). In comparison to pure HA coating, HA-4C represents $118.24 \pm 3.97 \%$ higher bacterial adhesion. The dense $E$. coli colonies on the HA-4C sample confirms the role of CNT assisting in the E. coli adhesion and proliferation also reported by [22]. While considering the composite HA-4C-5Ce, an almost similar (115.4 $\pm 2.43 \%)$ bacterial density is obtained as in the case of HA-4C $(118.24 \pm 3.97 \%)$. The inert nature of $\mathrm{CeO}_{2}$ toward E. coli has also been reported earlier $[23,58]$. The character of silver is evident considering the least bacterial adhesion $(64.04 \pm 3.97 \%)$ on the HA-4C-5Ce-Ag composite coating. The -SH group of many enzymes are targeted by the permeating Ag ions through the bacterial membrane, thereupon restricting protein synthesis. Furthermore, the bacterial DNA is also denatured by Ag, subsequently causing bacterial death [19]. 

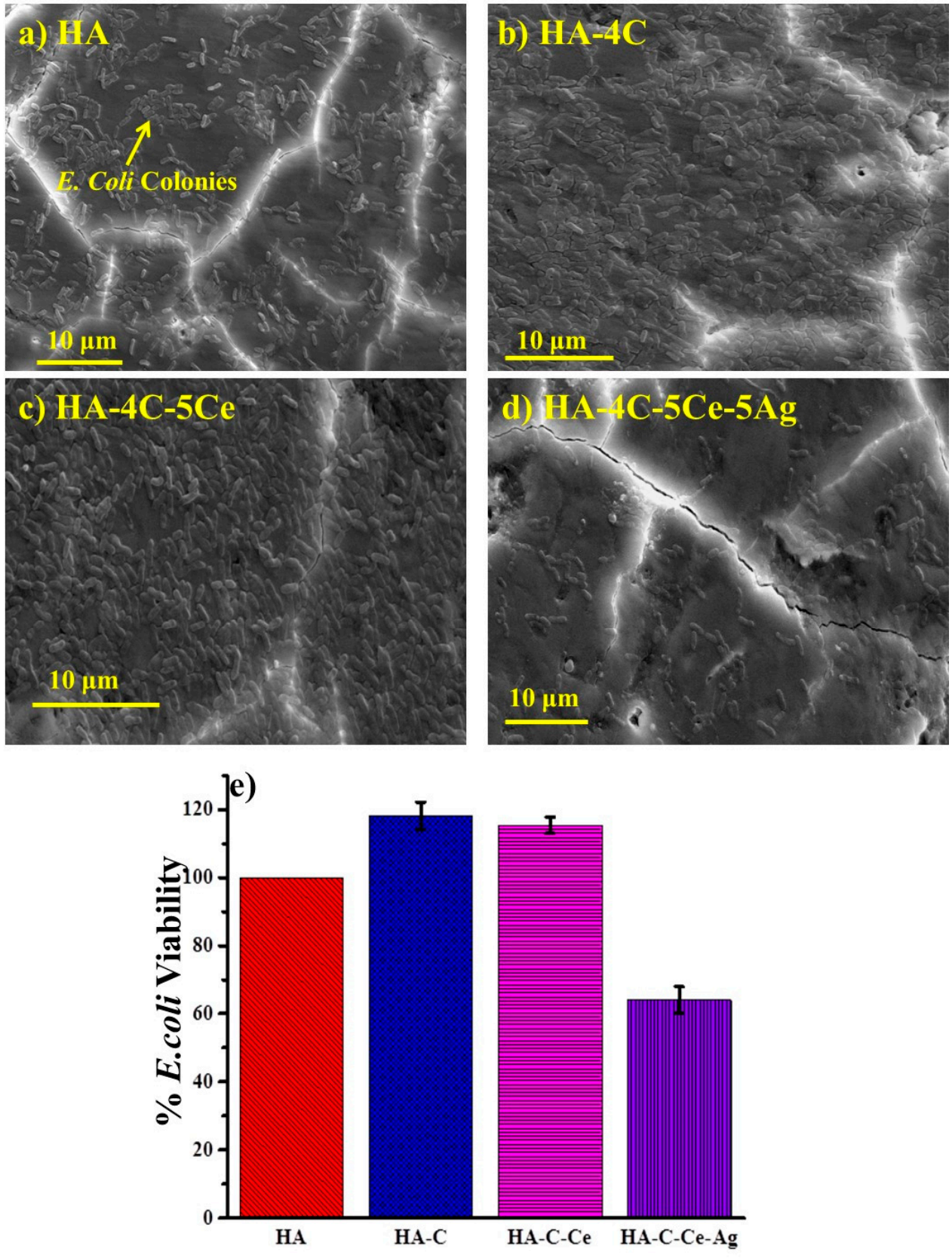

Figure 9. Scanning electron micrographs (a-d) and quantitative estimation (e) of E. coli on HA-based plasma sprayed coatings.

\subsection{Cytocompatibilty Test}

It can be observed from the SEM images (Figure 10a-d) of the cell seeded scaffolds that the pure HA coating (Figure 10a) shows elongated structures called filopodia of 10-20 $\mu \mathrm{m}$ in length that appear to extend into filopodia-like-extensions ranging from $40-60 \mu \mathrm{m}$, with CNT reinforcement (Figure 10b), and further develop into more complex actin cytoplasmic connections (multiple filopodia developed from more than direction) with $\mathrm{CeO}_{2}$ (Figure 10c) and/or $\mathrm{Ag}$ (Figure 10d) reinforcement. This confirms the supporting nature of reinforcement materials (used in the coatings) towards the cell adhesion process. In other words, the HA-4C-5Ce-Ag loaded supports acted as a better microenvironment for L929 cells (stretched with filopodia and cytoplasmic extensions) than the pure HA coating, which is confirmed by the proliferation experiment. 

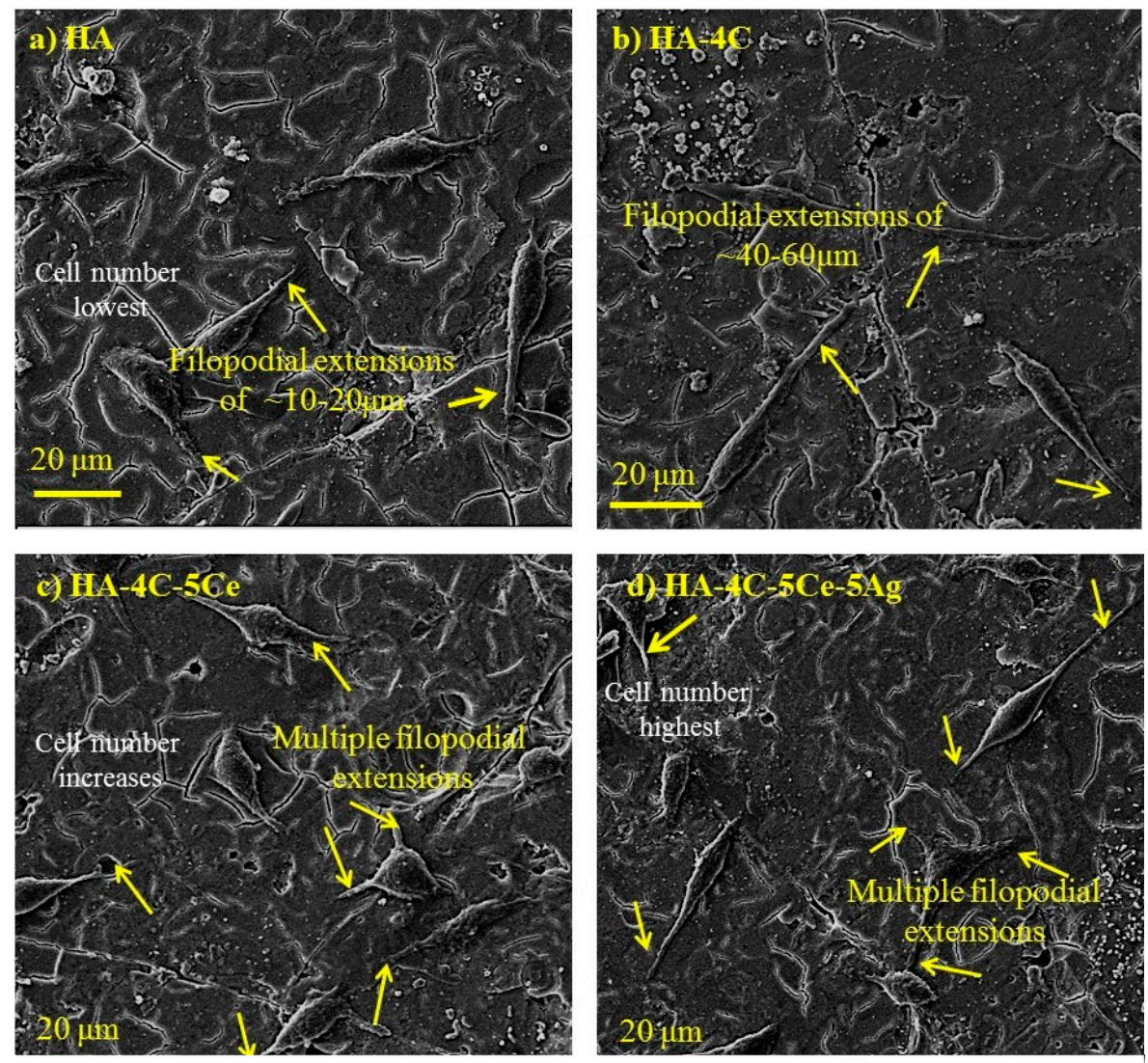

e)

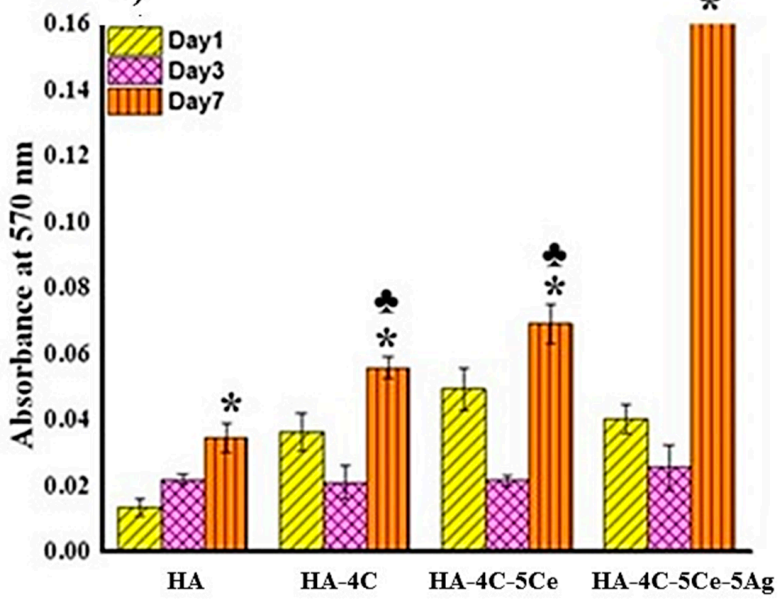

Figure 10. Scanning electron micrographs (a-d) and quantitative estimation (e) of L929 cells on HA-based plasma sprayed coatings. ${ }^{*}$ Indicates $p$ values of $<0.007$ for cell density average at day 7 of composites when compared to day $7 \mathrm{HA}$ control. The average of the obtained cell number on day 7 composites in comparison to that of same composites on day 1 and \& depicts $p$ value of $<0.001$.

Figure 10e presents the MTT assay results carried out with the L929 cells cultured on the pure HA and composite plasma sprayed coatings. Cell adhesion and proliferation after day 1 revealed an enhancement in cellular viability (majorly due to the fetal bovine serum protein adsorption from the media during the incubation period, overnight) on all the composite coatings in comparison to the pure HA coating. It can be noticed that the highest number of cells were obtained on HA-4C-5Ce construct (3.7 times than that of HA), which relates to the highest protein adsorption on the same (Table 3), which is attributed to the hydrophobic effect of $\mathrm{CNT}$ and $\mathrm{CeO}_{2}$. The cell count on HA-4C-Ce-Ag 
sample (3.0 times higher relative to HA) was higher than HA-4C (2.7 times higher relative to HA), again following the similar trend of the protein adsorption.

However, the day 2 readings show a downfall of the cell number on the samples containing $\mathrm{CNT}, \mathrm{CeO}_{2}$, or $\mathrm{Ag}$ due to their hydrophobic nature, now governing the cell interaction process. This is because of the occurring protein adsorption up to $48 \mathrm{~h}$, after which the desorbed protein so not play a role in the cell-interaction process, now leaving the cell-adhesion to be controlled by the surface properties of the samples [59]. The increment in cell numbers when compared to day 1 of the same sample was achieved maximum for pure HA (1.6 times higher than day $1 \mathrm{HA}$ ). There was an observed cell density decrease on the hydrophobic HA-4C-5Ce-Ag (1.6 times lower than day 1 HA-4C-5Ce- $\mathrm{Ag}$ ) and HA-4C (1.7 times lesser than day $1 \mathrm{HA}-4 \mathrm{C})$, with the maximum decrement on the most hydrophobic HA-4C-5Ce (2.3 times lesser than day 1 HA-4C-5Ce) coating. Peculiarly, the cell numbers on HA, HA-4C and HA-4C-5Ce were found to almost in the same range, with the best density on HA-4C-5Ce-Ag, indicating it to support cell adhesion and proliferation in comparison to all the remaining coatings, as surface is well-covered (confluent) with cells.

The day 7 reading, nonetheless, increased the cell densities on all the substrates when compared to day 1 . Besides, the cell numbers on the all the reinforced samples was higher than pure HA day 7. This is due to the physiological activities like extra cellular matrix mineralization of the cells, after $72 \mathrm{~h}$ (post-mitotic period), during which the actual surface properties of substrate may not influence cellular adhesion or proliferation [60].

Although cell proliferation was high on all composite supports, throughout the incubation period, the largest densities were collected on the HA-4C-5Ce-Ag loaded constructs (4.8 times higher, attributed to the synergistic effect of $\mathrm{CNT}, \mathrm{CeO}_{2}$ and $\mathrm{Ag}$ ), followed by $\mathrm{HA}-4 \mathrm{C}-\mathrm{Ce}$ coated sample increased 2.0 times and $\mathrm{HA}-4 \mathrm{C}$ increased 1.6 times relative to $\mathrm{HA}$ day 7. The cell density is found to increase with $\mathrm{CeO}_{2}$ (resemblance with $\mathrm{Ca}^{2+}$ assisting in cell growth [61,62]) and $\mathrm{Ag}$ (the low/nil cytotoxicity of Ag when used in low concentration [22]) reinforcement, as already stated elsewhere [23]. The cell number on the HA-4C sample was found to be the least amongst the composite coatings, however this (CNT reinforced HA coated sample) gave rise to much better cell adhesion and proliferation (1.6 times) when compared to pure HA coating which can be attributed to the inclining properties of the CNTs toward cell growth as reported by $[22,25,32]$. This confirms that the HA-4C-5Ce-Ag to support cell growth and is an optimal substrate for its use in orthopedic applications.

The schematic in Figure 11 presents the mechanical, tribological, and biological properties of HA-based plasma-sprayed coatings on TiAl6V4 substrate. The pure HA coating (Figure 11a) shows the lowest mechanical property (toughness of $0.68 \mathrm{MPa} \cdot \mathrm{m}^{1 / 2}$, Table 1 ) and therefore the least tribological resistance (wear rate of $176.1 \times 10^{-5} \mathrm{~mm}^{3} \cdot \mathrm{N}^{-1} \cdot \mathrm{m}^{-1}$, Table 2), the least L929 cell density, and no antibacterial property. For the CNT incorporated HA-4C coating (Figure 11b), the increased toughness by 1.3 times (Table 1 ) and the CNT pull-outs from the matrix led to the formation of graphitic tribo-film (Figure 6b), tribological resistance by 3 times (Table 2) with 1.6 times higher cell growth (with filopodial protrusions) and 18\% higher bacterial growth. The fracture toughness (attributed to the crack bridging by $\mathrm{CNTs}$ and toughening by $\mathrm{CeO}_{2} \mathrm{NPs}$ ) and tribological resistance by 1.6 times and 18 times higher, respectively, while cell density (with multiple filopodial protrusions) was enhanced by 2 times but with 15\% higher bacterial growth (Figure 11c). Figure 11d (HA-4C-5Ce-5Ag) shows 3.1 times higher toughness, 26 times higher wear resistance, 4.8 times elevated cell density, and $46 \%$ bacterial reduction (in comparison to HA coating). The fracture toughness is enhanced by the synergistic effect of CNT pull-outs and crack bridging, and volumetric toughening provided by $\mathrm{CeO}_{2}$ and $\mathrm{Ag} \mathrm{NPs}$. There was increased cell density again due to synergy between the reinforcements, leading to development of multiple filopodial protrusions (of $\sim 40 \mu \mathrm{m}$ ). The flat and elongated cells further confirm the contact-intimacy with the coating. The bactericidal Ag NPs lead to decrement in E. coli density due to denaturing DNA and the proteins. Thus, $\mathrm{CNT}, \mathrm{CeO}_{2}$ and $\mathrm{Ag}$ incorporated $\mathrm{HA}$ coating leads to enhanced mechanical, cytocompatible, and antibacterial efficacy. 

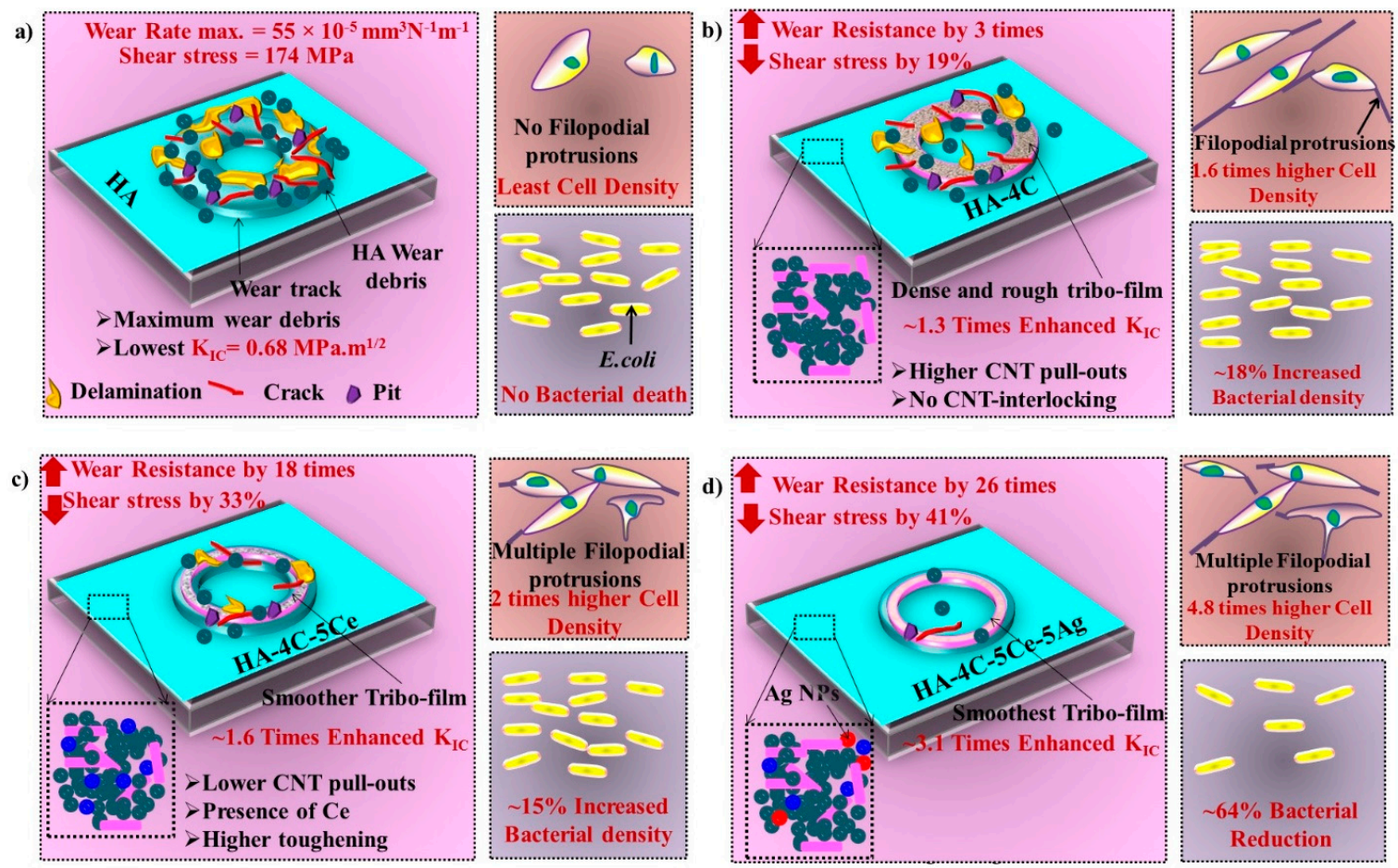

Figure 11. Schematic representing the plausible mechanisms involved for tribological resistance and fracture toughness, cell density, and bacterial adhesion on (a) HA-, (b) HA-4C-, (c) HA-4C-5Ce-, and (d) HA-4C-5Ce-5Ag-coated TiAl6V4 substrate.

\section{Conclusions}

The HA-based coatings were plasma-sprayed on TiAl6V4, and the obtained coating thickness was $100-130 \mu \mathrm{m}$. HA-CNT-CeO ${ }_{2}$-Ag plasma-sprayed coating elicited a tribological resistance of 28 times more than that of pure HA coating attributed to the combined effect of deposited graphitic tribo-film and enhanced mechanical properties (2.3 times 1.6 times, and 3.1 times enhanced Vickers hardness, estimated modulus, and fracture toughness, respectively). The resulting shear stress for HA coating was estimated to be maximum $(173.7 \mathrm{MPa})$, which reduced to $102.9 \mathrm{MPa}$ with $\mathrm{CNT}-\mathrm{CeO}_{2}-\mathrm{Ag}$ reinforcement. The Archard's wear constant was computed to be decreased by an order of magnitude for HA-CNT- $-\mathrm{CeO}_{2}$ and HA-CNT- $-\mathrm{CeO}_{2}-\mathrm{Ag}$, which portrays the wear resistance being governed by the hardness of the material. Furthermore, the highest stress (due to a maximum of $1.1 \mathrm{GPa}$ Hertzian contact pressure and $0.16 \mathrm{COF}$ amongst coatings) generated, for HA, consequently led to maximum worn volume (30 times more than HA-4C-4Ce-5Ag). The 19\% lower stress generated for the CNT-reinforced coatings due to lubrication from graphitization and the higher mechanical property $\left(H, K_{I C}\right)$ led to a 3 times decrement (than $\left.\mathrm{HA}\right)$ in the worn volume. The combined action of lowest Hertzian contact stresses ( $33 \%$ for $\mathrm{HA}-\mathrm{CNT}-\mathrm{CeO}_{2}$ and $41 \%$ for $\mathrm{HA}-\mathrm{CNT}-\mathrm{CeO}_{2}-\mathrm{Ag}$, relative to $\mathrm{HA}$ ) and the highest hardness and toughness resulted in 20 and 30 times reduction of wear volume for $\mathrm{CeO}_{2}$ - and $\mathrm{CeO}_{2}-\mathrm{Ag}$-incorporated $\mathrm{HA}-\mathrm{CNT}$ coatings, respectively. The composite coating was found to be bactericidal for $E$. coli ( $46 \%$ reduced bacterial adhesion), elicited by the Ag reinforcement. Maximum fibroblast adhesion was attained on HA-4C-5Ce-5Ag construct on day 7 due to the synergistic effect of reinforcing materials, concluding the non-toxicity of the used $\mathrm{CNTs}, \mathrm{CeO}_{2}$, and $\mathrm{Ag}$ (in lower concentrations) toward the $\mathrm{L} 929$ cell line. Hence, it is concluded that the $\mathrm{HA}-\mathrm{CNT}-\mathrm{CeO}_{2}-\mathrm{Ag}$ plasma-sprayed coating successfully enhanced the wear resistance due to enhanced hardness and toughness (accredited to synergistic role of reinforcements) and was also found to be cytocompatible and bactericidal, thus making it a potential substrate for hard-tissue replacements. 
Author Contributions: Conceptualization, K.B.; Methodology, A.P., A.K.P., A.S. and V.K.; Software, A.P.; Validation, R.K.S., K.B. and A.P.; Formal Analysis, A.K.P., A.S., R.K.S., V.K. and S.K.; Investigation, A.P. and A.K.P; Resources, K.B., A.A. and A.K.K.; Data Curation, A.P.; Writing-Original Draft Preparation, A.P.; Writing-Review \& Editing, A.S.; Visualization, A.P.; Supervision, V.K.N. and K.B.; Project Administration, K.B.; Funding Acquisition, K.B.

Funding: MHRD and Swarnajayanti Fellowship (DST/SJF/ETA-02/2016-17), Department of Science and Technology, Govt. of India.

Acknowledgments: K.B. acknowledges indentation facility in Advanced Center for Materials Science, IIT Kanpur.

Conflicts of Interest: The authors declare no conflict of interest.

\section{References}

1. Hench, L.L. Bioceramics: From concept to clinic. J. Am. Ceram. Soc. 1991, 74, 1487-1510. [CrossRef]

2. Jarcho, M. Calcium phosphate ceramics as hard tissue prosthetics. Clin. Orthop. Relat. Res. 1981, 157, $259-278$. [CrossRef]

3. Joshi, S.V.; Srivastava, M.P.; Pal, A.; Pal, S. Plasma spraying of biologically derived hydroxyapatite on implantable materials. J. Mater. Sci. Mater. Med. 1993, 4, 251-255. [CrossRef]

4. Piattelli, A.; Trisi, P. A light and laser scanning microscopy study of bone/hydroxyapatite-coated titanium implants interface: Histochemical evidence of unmineralized material in humans. Biomed. Mater. Res. 1994, 28, 529-536. [CrossRef] [PubMed]

5. Prakasam, M.; Locs, J.; Salma-Ancane, K.; Loca, D.; Largeteau, A.; Berzina-Cimdina, L. Fabrication, Properties and Applications of Dense Hydroxyapatite: A Review. J. Funct. Biomater. 2015, 6, 1099-1140. [CrossRef] [PubMed]

6. With, G.D.; Van Dijk, H.J.A.; Hattu, N.; Prijs, K. Preparation, micro-structure and mechanical properties of dense polycrystalline hydroxy-apatite. J. Mater. Sci. 1981, 16, 1592-1598. [CrossRef]

7. Wennerberg, A.; Albrektsson, T. Structural influence from calcium phosphate coatings and its possible effect on enhanced bone integration. Acta Odontol. Scand. 2009, 67, 333-340. [CrossRef] [PubMed]

8. Manara, S.; Paolucci, F.; Palazzo, B.; Marcaccio, M.; Foresti, E.; Tosi, G.; Sabbatini, S.; Sabatino, P.; Altankov, G.; Roveri, N. Electrochemically-assisted deposition of biomimetic hydroxyapatite-collagen coatings on titanium plate. Inorg. Chim. Acta 2008, 361, 1634-1645. [CrossRef]

9. Wu, C.; Ramaswamy, Y.; Gale, D.; Yang, W.; Xiao, K.; Zhang, L.; Yin, Y.; Zreiqat, H. Novel sphene coatings on Ti-6Al-4V for orthopedic implants using sol-gel method. Acta Biomater. 2008, 4, 569-576. [CrossRef] [PubMed]

10. Liang, H.; Shi, B.; Fairchild, A.; Cale, T. Applications of plasma coatings in artificial joints: An overview. Vacuum 2004, 73, 317-326. [CrossRef]

11. Gotman, I. Characteristics of metals used in implants. J. Endourol. 1997, 6, 383-389. [CrossRef] [PubMed]

12. Wang, J.X.; Fan, Y.B.; Gao, Y.; Hu, Q.H.; Wang, T.C. $\mathrm{TiO}_{2}$ nanoparticles translocation and potential toxicological effect in rats after intraarticular injection. Biomaterials 2009, 30, 4590-4600. [CrossRef] [PubMed]

13. Gu, Y.W.; Khor, K.A.; Cheang, P. In vitro studies of plasma-sprayedhydroxyapatite/Ti-6Al-4V composite coatings in simulated body fluid (SBF). Biomaterials 2003, 24, 1603-1611. [CrossRef]

14. Chen, Y.; Gan, C.; Zhang, T.; Yu, G. Laser-surface-alloyed carbon nanotubes reinforced hydroxyapatite composite coatings. Appl. Phys. Lett. 2005, 86, 251905. [CrossRef]

15. Hukovic, M.M.; Tkalcec, E.; Kwokal, A.; Piljac, J. An in vitro study of Ti and Ti-alloys coated with sol-gel derived hydroxyapatite coatings. Surf. Coat. Technol. 2003, 165, 40-50. [CrossRef]

16. Liu, D.M.; Troczynski, T.; Tseng, W.J. Water based sol-gel synthesis of hydroxyapatite: Process development. Biomaterials 2001, 22, 1721-1730. [CrossRef]

17. Sarikaya, M.; Tamerler, C.; Jen, A.K.Y.; Schulten, K.; Baneyx, F. Molecular biomimetics: Nanotechnology through biology. Nat. Mater. 2003, 2, 577-585. [CrossRef] [PubMed]

18. Kanhed, S.; Awasthi, S.; Goel, S.; Pandey, A.; Sharma, R.; Upadhyaya, A.; Balani, K. Porosity Distribution Affecting Mechanical and Biological Behaviour of Hydroxyapatite Bioceramic Composites. Ceram. Int. 2017, 43, 10442-10449. [CrossRef]

19. Afzal, M.A.F.; Kalmodia, S.; Kesarwani, P.; Basu, B.; Balani, K. Bactericidal effect of silver-reinforced carbon nanotube and hydroxyapatite composites. J. Biomater. Appl. 2013, 27, 967-978. [CrossRef] [PubMed] 
20. Afzal, M.A.; Kesarwani, P.; Reddy, K.M.; Kalmodia, S.; Basu, B.; Balani, K. Functionally graded hydroxyapatitealumina-zirconia biocomposite:Synergy of toughness and biocompatibility. Mater. Sci. Eng. C 2012, 32, 1164-1173. [CrossRef]

21. Lee, S.S.; Song, W.; Cho, M.; Puppala, H.L.; Nguyen, P.; Zhu, H.; Segatori, L.; Colvin, V.L. Antioxidant Properties of Cerium Oxide Nanocrystals as a Function of Nanocrystal Diameter and Surface Coating. ACS Nano 2013, 7, 9693-9703. [CrossRef] [PubMed]

22. Herkendell, K.; Shukla, V.R.; Patel, A.K.; Balani, K. Domination of volumetric toughening by silver nanoparticles over interfacial strengthening of carbon nanotubes in bactericidal hydroxyapatite biocomposite. Mater. Sci. Eng. C Mater. Biol. Appl. 2014, 34, 455-467. [CrossRef] [PubMed]

23. Pandey, A.; Midha, S.; Sharma, R.; Maurya, R.; Nigam, V.; Ghosh, S.; Balani, K. Antioxidant and Antibacterial Property of Hydroxyapatite Biocomposites. Mater. Sci. Eng. C 2017. [CrossRef]

24. Mullins, L.P.; Bruzzi, M.S.; McHugh, P.E. Measurement of the microstructural tracture toughness of cortical bone using indentation fracture. J. Biomech. 2007, 40, 3285-3288. [CrossRef] [PubMed]

25. Balani, K.; Anderson, R.; Laha, T.; Andara, M.; Tercero, J.; Crumpler, E.; Agarwal, A. Plasma-sprayed carbon nanotube reinforced hydroxyapatite coatings and their interaction with human osteoblasts in vitro. Biomaterials 2007, 28, 618-624. [CrossRef] [PubMed]

26. Duong, H.M.; Gong, F.; Liu, P.; Tran, T.Q. Advanced Fabrication and Properties of Aligned Carbon Nanotube Composites: Experiments and Modeling. In Carbon Nanotubes-Current Progress of their Polymer Composites; Berber, M.R., Hafez, I.H., Eds.; InTech Open: San Francisco, CA, USA, 2016.

27. Khoshnevis, H.; MyoMint, S.; Yedinak, E.; Tran, T.Q.; Zahoush, A.; Youssefi, M.; Pasquali, M.; Duong, H.M. Super high-rate fabrication of high-purity carbon nanotube aerogels from floating catalyst method for oil spill cleaning. Chem. Phys. Lett. 2018, 693, 146-151. [CrossRef]

28. Rajesh, R.; Senthilkumar, N.; Hariharasubramanian, A.; Ravichandran, Y.D. Review on hydroxyapatitecarbon nanotube composites and some of their Applications. Int. J. Pharm. Pharm. Sci. 2012, 4, 23-27.

29. Chlopek, J.; Czajkowska, B.; Szaraniec, B.; Frackowiak, E.; Szostak, K.; Beguin, F. In vitro studies of carbon nanotubes biocompatibility. Carbon 2006, 44, 1106-1111. [CrossRef]

30. Zanello, L.P.; Zhao, B.; Hu, H.; Haddon, R.C. Bone cell proliferation on carbon nanotubes. Nano Lett. 2006, 6, 562-567. [CrossRef] [PubMed]

31. Usui, Y.; Aoki, K.; Narita, N.; Murakami, N.; Nakamura, I.; Nakamura, K. Carbon nanotubes with high bone-tissue compatibility and bone-formation acceleration effects. Small 2008, 4, 240-246. [CrossRef] [PubMed]

32. Lahiri, D.; Singh, V.; Keshri, A.K.; Seal, S.; Agarwal, A. Carbon nanotube toughened hydroxyapatite by spark plasma sin-tering: Microstructural evolution and multi-scale tribological properties. Carbon 2010, 48, 3103-3120. [CrossRef]

33. Balani, K.; Lahiri, D.; Keshri, A.K.; Bakshi, S.R.; Tercero, J.E.; Agarwal, A. The Nano-scratch Behavior of Biocompatible Hydroxyapatite Reinforced with Aluminum Oxide and Carbon Nanotubes. JOM J. Miner. Met. Mater. Soc. TMS 2009, 61, 63-66. [CrossRef]

34. Rouahi, M.; Champion, E.; Hardouin, P.; Anselme, K. Quantitative kinetic analysis of gene expression during human osteoblastic adhesion on orthopedic materials. Biomaterials 2006, 27, 2829-2844. [CrossRef] [PubMed]

35. Hsu, F.Y.; Chueh, S.C.; Wang, Y.J. Microspheres of hydroxyapatite/reconstituted collagen as supports for osteoblast cell growth. Biomaterials 1999, 20, 1931-1936. [CrossRef]

36. Ramires, P.A.; Romito, A.; Cosentino, F.; Milella, E. The influence of titania/hydroxyapatite composite coatings on in vitro osteoblasts behaviour. Biomaterials 2001, 22, 1467-1474. [CrossRef]

37. Kumar, V.; Sinha, S.K.; Agarwal, A.K. Tribological studies of epoxy composites with solid and liquid fillers. Tribol. Int. 2017, 105, 27-36. [CrossRef]

38. Murab, S.; Chameettachal, S.; Ghosh, S. Establishment of an in vitro monolayer model of macular corneal distrophy. Lab. Investig. Nat. Publ. Group 2016, 96, 1311-1326. [CrossRef] [PubMed]

39. Lawn, B.R.; Anstis, G.R.; Chantikul, P.; Marshall, D.B. A critical evaluation of indentation techniques for measuring fracture toughness: I, direct crack measurements. J. Am. Ceram. Soc. 1981, 64, 533-538.

40. Nath, S.; Kalmodia, S.; Basu, B. Densification, phase stability and in vitro biocompatibility property of hydroxyapatite-10 wt\% silver composites. J. Mater. Sci. Mater. Med. 2010, 21, 1273-1287. [CrossRef] [PubMed]

41. Kelly, P.M.; Francis Rose, L.R. The martensitic transformation in ceramics-its role in transformation toughening. Prog. Mater. Sci. 2002, 47, 463-557. [CrossRef] 
42. Hannink, R.H.J.; Kelly, P.M.; Muddle, B.C. Transformation toughening in zirconia-containing ceramics. J. Am. Ceram. Soc. 2000, 83, 461-487. [CrossRef]

43. Zhang, C.; Nieto, A.; Agarwal, A. Ultrathin graphene tribofilm formation during wear of $\mathrm{Al}_{2} \mathrm{O}_{3}$-graphene composites. Nanomater. Energy 2016, 5, 1-9. [CrossRef]

44. Pandey, A.; Nigam, V.K.; Balani, K. Effect of Ceria and Silver Reinforcement on Multi-length Scale Tribology of Hydroxyapatite. Wear 2017. under review.

45. Wu, P.Q.; Chen, H.; Stappen, M.V.; Stals, L.; Celisa, J.-P. Comparison of fretting wear of uncoated and PVD TiN coated high-speed steel under different testing conditions. Surf. Coat. Technol. 2000, 127, 114-119. [CrossRef]

46. Balani, K.; Harimkar, S.P.; Keshri, A.; Chen, Y.; Dahotre, N.B.; Agarwal, A. Multiscale wear of plasma-sprayed carbon-nanotube-reinforced aluminum oxide nanocomposite coating. Acta Mater. 2008, 56, 5984-5994. [CrossRef]

47. De Nicola, F.; Castrucci, P.; Scarselli, M.; Nanni, F.; Cacciotti, I.; De Crescenzi, M. Super-hydrophobic multi-walled carbon nanotube coatings for stainless steel. Nanotechnology 2015, 26, 145701. [CrossRef] [PubMed]

48. Azimi, G.; Dhiman, R.; Hyuk-Min, K.; Paxton, A.T.; Varanasi, K.K. Hydrophobicity of Rare-earth Oxide Ceramics. Nat. Mater. 2013, 12, 315-320.

49. Tsukuma, K.; Shimada, M. Strength, Fracture Toughness and Vickers Hardness of $\mathrm{CeO}_{2}$ Stabilized Tetragonal $\mathrm{ZrO}_{2}$ Polycrystals. J. Mater. Sci. 1985, 20, 1178-1184. [CrossRef]

50. Giovambattista, N.; Debenedetti, P.G.; Rossky, P.J. Effect of Surface Polarity on Water Contact Angle and Interfacial Hydration Structure. J. Phys. Chem. B 2007, 111, 9581-9587. [CrossRef] [PubMed]

51. Pratik, K.C.; Nammari, A.; Ashton, T.S.; Adjei, I.M. Saturated pool boiling heat transfer from vertically oriented silicon surfaces modified with foam-like hexagonal boron nitride nanomaterials. Int. J. Heat Mass Transf. 2016, 95, 964-971. [CrossRef]

52. Tanaka, M.; Motomura, T.; Kawada, M.; Anzai, T.; Kasori, Y.; Shiroya, T.; Shimura, K.; Onishi, M.; Mochizuki, A. Blood compatible aspects of poly(2-methoxyethylacrylate) (PMEA)-relationship between protein adsorption and platelet adhesion on PMEA surface. Biomaterials 2000, 21, 1471-1481. [CrossRef]

53. Wertz, C.F.; Santore, M.M. Effect of Surface Hydrophobicity on Adsorption and Relaxation Kinetics of Albumin and Fibrinogen:Single-Species and Competitive Behavior. Langmuir 2001, 17, 3006-3016. [CrossRef]

54. Ravindran, A.; Singh, A.; Raichur, A.M.; Chandrasekaran, N.; Mukherjee, A. Studies on interaction of colloidal Ag nanoparticles with Bovine Serum Albumin (BSA). Colloids Surf. B Biointerfaces 2010, 76, 32-37. [CrossRef] [PubMed]

55. Norde, W. My voyage of discovery to proteins in flatland ... and beyond. Colloids Surf. B Biointerfaces 2008, 61, 1-9. [CrossRef] [PubMed]

56. Carter, D.C.; Ho, J.X. Structure of Serum Albumin. Adv. Protein Chem. 1994, 45, 153-203. [PubMed]

57. Podstawka, E.; Ozaki, Y.; Proniewicz, L.M. Adsorption of S-S containing proteins on a colloidal silver surface studied by surface-enhanced Raman spectroscopy. Appl. Spectrosc. 2004, 58, 1147-1156. [CrossRef] [PubMed]

58. Thill, A.; Zeyons, O.L.; Spalla, O.; Chauvat, F.; Rose, J.M.; Auffan, M.L.; Flank, A.M. Cytotoxicity of CeO Nanoparticles for Escherichia coli. Physico-Chemical Insight of the Cytotoxicity Mechanism. Environ. Sci. Technol. 2006, 40, 6151-6156. [CrossRef] [PubMed]

59. Swain, S.K.; Sarkar, D. Study of BSA protein adsorption/release on hydroxyapatite nanoparticles. Appl. Surf. Sci. 2013, 286, 99-103. [CrossRef]

60. Liu, X.; Lim, J.Y.; Donahue, H.J.; Dhurjati, R.; Mastro, A.M.; Vogler, E.A. Influence of substratum surface chemistry/energy and topography on the human fetal osteoblastic cell line hFOB 1.19: Phenotypic and genotypic responses observed in vitro. Biomaterials 2007, 28, 4535-4550. [CrossRef] [PubMed]

61. Jowsey, J.; Rowland, R.E.; Marshall, J.H. The deposition of the rare earths in bone. Radiat. Res. 1958, 8, 490-501. [CrossRef] [PubMed]

62. Riccardi, D.; Finney, B.; Wilkinson, W.; Kemp, P. Novel regulatory aspects of the extracellular Ca ${ }^{2+}$-sensing receptor, CaR. Pflïg. Arch. Eur. J. Phys. 2009, 458, 1007-1022. [CrossRef] [PubMed]

(C) 2018 by the authors. Licensee MDPI, Basel, Switzerland. This article is an open access article distributed under the terms and conditions of the Creative Commons Attribution (CC BY) license (http:// creativecommons.org/licenses/by/4.0/). 